\title{
Eemian estuarine record forced by glacio-isostasy (southern Iceland)-link with Greenland and deep sea records
}

\author{
Van Vliet-Lanoe Brigitte ${ }^{1,}{ }^{*}$, Schneider Jean-Luc ${ }^{2}$, Gudmundsson Agust ${ }^{3}$, Guillou Herve ${ }^{4}$, Nomade \\ Sebastien ${ }^{4}$, Chazot Gilles ${ }^{1}$, Liorzou Celine ${ }^{1}$, Guegan Solene ${ }^{1,5}$
}

1 UBO, IUEM, UMR Geosci Ocean 6538, PI N Copernic, F-29280 Plouzane, France.

2 Univ Bordeaux, CNRS, UMR EPOC 5805, Allee G St Hilaire, F-33615 Pessac, France.

3 Jardfraedistofan Ehf, Hafnarfjordur, Iceland.

4 LSCE, Domaines CNRS, Bat 12 Av Terrasse, F-91198 Gif Sur Yvette, France.

${ }^{5}$ BCRMarine Brest, Serv Logist, CC50, F-29240 Brest 9, France.

${ }^{*}$ Corresponding author : Brigitte Van Vliet-Lanoe, email address : brigitte.vanvlietlanoe@univ-brest.fr

\begin{abstract}
:
Central southern Iceland is one of the main outlets of the Icelandic Ice Sheet where a MIS 5e sedimentary complex, the Ranga Formation, is extensively observed below the last deglaciation terminal moraines. Sedimentary facies demonstrate that the Ranga Formation is mostly tidal, up to $215 \mathrm{~m}$ (transgression I) and $168 \mathrm{~m}$ (transgression II) in altitude. The first highstand reworks a thick tephra from the Grimsvotn volcano, known in marine cores as $5 \mathrm{e}$ low/Bas-IV and positioned at ca. $127 \mathrm{Ka} \mathrm{BP}$, the Eemian thermal optimum. This formation is related to a rapid deglaciation followed by two marine transgressions marked by the development of extended mud flats, which were separated by a complex regression phase, associated with loess deposition, ca. $9 \mathrm{Ka}$ in duration. Palaeo jokulhlaups, basaltic flows, and tephra fallouts from the Hekla and Grimsvotn volcanoes affected the sedimentation. The Ranga Formation yields one of the first continuous and complete estuarine records of the Eemian interglacial in Iceland and probably for most of the northern terrestrial Atlantic. This estuarine infill records the distal signature of a complex glacial advance within the last interglacial, already well identified in northern and central Iceland. The glacial advance is attributed to the intra-Eemian cooling events (Greenland GS 26 or marine cold events M-C25-C26). It is followed by a warming and a glacial retreat corresponding to the Greenland GI 25 event. This formation allows, in connection with the timing of recognized volcanic periods, a better insight of the interconnections between sea-level, regional glacial extent, and Northern Hemisphere marine and ice core climatic records.
\end{abstract}

\section{Résumé :}

Le centre de l'Islande méridionale est un des exutoires de la calotte glaciaire islandaise. Un complexe sédimentaire du MIS 5e, la Formation Rangá, y est préservé sous les moraines terminales de la dernière déglaciation. Les faciès sédimentaires de cette formation sont tidaux et enregistrent deux hauts niveaux marins successifs jusqu'à $215 \mathrm{~m}$ (transgression I) et $168 \mathrm{~m}$ (transgression II) d'altitude. Lors de l'optimum thermique éémien vers $127 \mathrm{Ka} \mathrm{BP}$, le premier haut niveau a remanié un épais téphra du volcan Grimsvötn, 
le 5e Bas-IV inférieur des carottes marines. La mise en place de cette formation est liée à une déglaciation rapide suivie par le développement de vasières étendues lors des hauts niveaux littoraux; une phase de régression complexe avec dépôt loessique d'une durée d'environ 9 k.a. les sépare. Des paléojökulhlaups, des coulées basaltiques et des téphras de l'Hekla et de Grimsvötn sont enregistrés. Cette formation constitue l'un des premiers enregistrement estuariens complets de l'Éémien en Islande et pour l'Atlantique Nord. Elle conserve la signature distale d'une avancée glaciaire complexe durant le dernier interglaciaire, déjà bien établie dans le nord et le centre de l'Islande. Cette avancée glaciaire est attribuée aux refroidissements intraéémiens (GS 26 au Groenland ou refroidissements marins M-C25-C26). Elle est suivie par un réchauffement et une déglaciation corrélée à l'événement $\mathrm{GI} 25$ du Groenland. Cette formation, en couplage avec des corrélations téphrostratigaphiques, permet une meilleure compréhension des interconnexions entre le niveau marin, l'extension régionale des calottes glaciaires et l'enregistrement climatique extrait des carottes marines et de glace pour l'hémisphère nord. [Traduit par la Rédaction] 


\section{Introduction}

Very few coastal sequences record the last interglacial close to the $60^{\circ} \mathrm{N}$ latitude. Last interglacial (MIS 5) sediments have been described at Fjosanger in central Norway $\left(60^{\circ} \mathrm{N}\right.$, Mangerud et al.1981; Hütt et al. 1983); at Cape Chelyuskin, Russian Arctic $\left(77^{\circ} \mathrm{N}\right.$, Möller et al. 2008); and in Jameson Land, eastern Greenland $\left(71^{\circ} \mathrm{N}\right.$; Hansen et al. 1997) but poorly constrained in time. No major coastal record of this interglacial has been observed in Iceland, except punctual undated outcrops along the northern coast $\left(66^{\circ} \mathrm{N}\right)$. The existence of an estuarine complex of this age in southern Iceland $\left(63-64^{\circ} \mathrm{N}\right.$, Fig. 1) should provide the key position of thecentral northern Atlantic Ocean information for linking marineevents recognized in marine cores to the ice sheet dynamic.The deglaciation deposits in southern Iceland (Fig. 1B) rest unconformably (Fig. 2) on a largely spread deglacial interglacial sedimentary coastal complex, brown-orange in color, the RangáFormation. It is constituted mainly of hyaloclastite sand, consolidated and faulted, including tephra and often deformed by glacitectonism.

It is also characterized by a pinnacle morphology(Fig. 3) sculptured by jökulhlaups (Maizels 1997), piercing locally the surface of the Late Glacial to Holocene well-dated sandur.

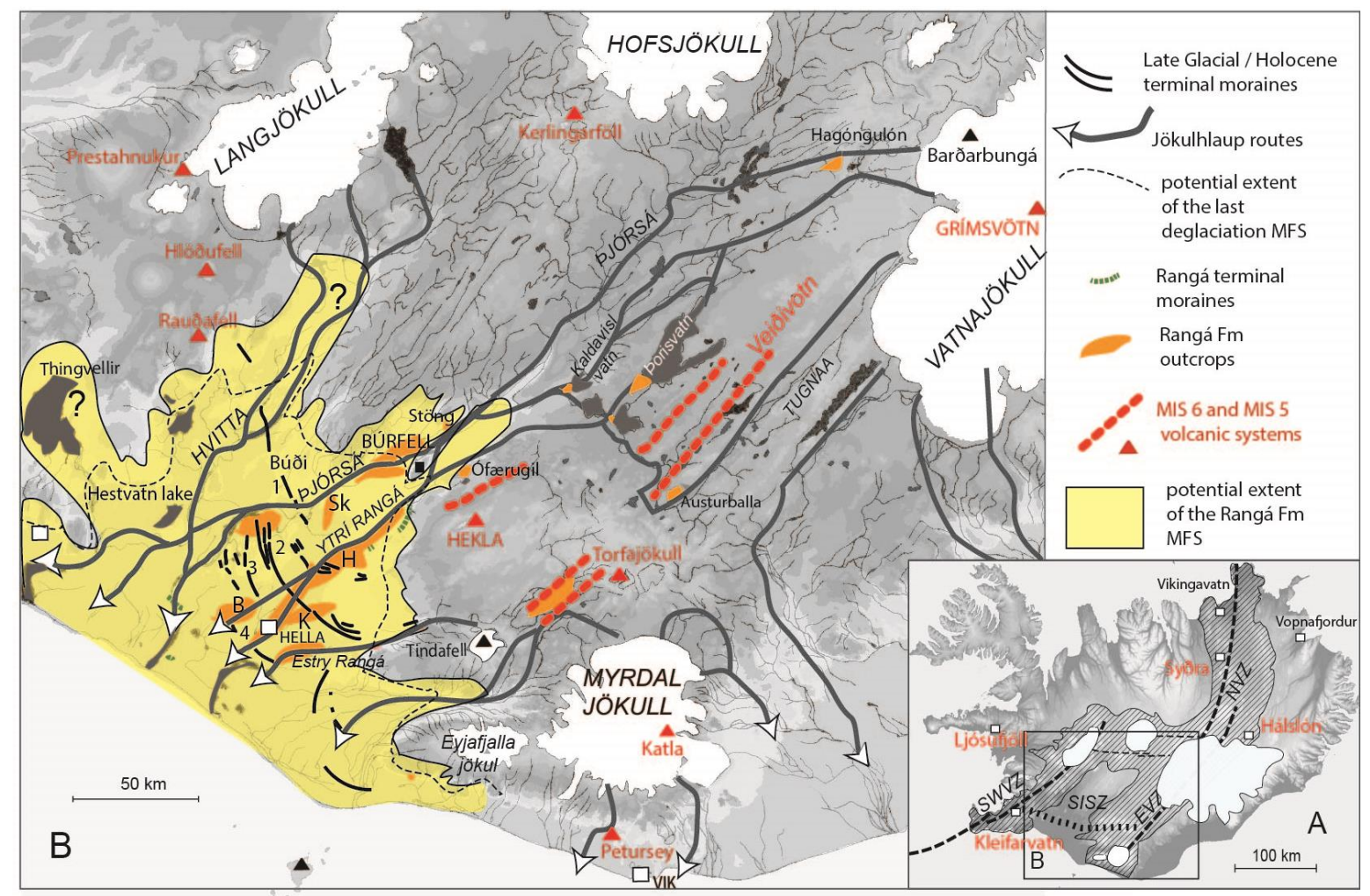

Fig. 1. Extent of the Ranga Formation compared to the last deglaciation flooding surface. Morainic arcs complexes: 1, Finse-Budi; 2, Mykjunes;3, Litlatunga; 4, Solvellir. Investigated sites: B, Bolstadur; K, Kirkjubar; H, Heidarbrekka; Sk, Skardsfjall; Stong, archeological site; O, Ofarugill;SWVZ, South-West Volcanic Zone; EVZ, East Volcanic Zone; NVZ, Northern Volcanic Zone; SISZ, South Icelandic Seismic Zone; Sydra, SydranordmalsfjellFormation. Boundary for the last deglaciation transgression (maximum flooding surface or MFS) is adopted from Geirsdottir et al. (2000). For details see Fig. 4.

It will be described as member R-C of the regional Quaternary record.This complex crops out discretely from Hágöngulón Lake to near the coast. The geotechnical properties of the Rangá sedimentsallowed in southern Iceland the excavation of subterraneous shelters by the early Gaels and Vikings (Ahronson 2015), as the Hellar 
Van Vliet-Lanoë, B., Schneider, J.L., Guormundsson, Á., Guillou, H., Nomade, S., Chazot, G., Liorziou, C., Guégan, S., 2017. Eemian estuarine record forced by glacio-isostasy (S Iceland) link with Greenland and deep sea records. Can. J. Earth Sc. In press

doi.org/10.1139/cjes-2017-0126

cave (Sk, Fig. 1B).The aim of this paper is to describe this Rangá Formation in its geological context and to extract its stratigraphic, glaciological,and palaeoclimatic meaning. Wepropose thus that this formation represents a continuous and complete estuarine record of theEemian interglacial in Iceland. The terrestrial record in tephrafrom this formation allows complementary correlation with these mostly published from marine cores (Davies et al. 2014). It brings a better insight of the interconnections between sea-level, glacial extent,and regional marine cores records. It is completive to our former studies focusing on a late interglacial complex from northern Iceland (Van Vliet-Lanoë et al. 2005, 2010). The geodynamical and volcano-seismic meaning will be analyzed in a subsequent publication.

\section{Methods}

Field studies were conducted from 2004 to 2015 and detailed mapping and sections description were made (full description with interpretation and photos are available in the supplementary data, File S11). Dry bulk density of sediment was measured by paraffin method (Brady 1990). Altitudes were obtained by GPS measurements compared with the revised topographical map of Iceland (1/50 000), giving an average error in $\mathrm{Z}$ of $\pm 5 \mathrm{~m}$. Petrographic analyses (thin sections, RX, and SEM) were performed in our respective laboratories with completive geochemical analyses performed at Brest University (File S21). Whole rock and tephra major and trace element analyses were performed for this paper only by ICP-AES, at IUEM Plouzané. Only thick basaltic tephra $(>3 \mathrm{~cm})$ were sampled from the consolidated outcrops to discriminate at first the tephra origin: thin sections revealed generally in the tephra a very high content in glass (>96\%) compared to mineral fraction (>98\%-95\% in Grim 1, 5, and 6). Variabilities already observed by ICP-AES with a specific "tephra" confirm a multi-event record (Syðra 1: three eruptive events). To be more accurate for the Vedde Ash and other major stratigraphical targets, rhyolitic tephra were analyzed by electron microprobe for major elements (Microsonde Ouest, Plouzané) and by laser ablation ICP-MS for trace elements. The thinner basaltic tephra will be further studied on thin sections and will be the object of a specific study with Laser ICP-MS and microprobe. A paper using the classical methodology (single grain ICP-MS and microprobe) for the tephrostratigraphy of the whole formation is in preparation. For the Holocene and Late Glacial, old radiocarbon dating were recalibrated using Calib.7.1, Marinecal13 with a suggested $R$ of 400 (Waelbroeck et al. 2001). Age of the lava flows are given in Table 1. Lava samples were dated (File S31) using the unspiked 40K-40Ar technique described by Charbit et al. (1998) and successively used to date the Quaternary volcanic samples from Iceland (Guillou et al. 2010). In this work, the procedures we follow for the sample preparations and for the mass spectrometric determination of argon composition are the same as those detailed in Guillou et al. (2010). Feldspars from pumice ISLN-112 (Hekla) were dated using the 40Ar/39Ar method detailed in File S31. Single crystals of feldspars from samples were $40 \mathrm{Ar} / 39 \mathrm{Ar}$ dated using single grain laser fusion. The yielded ages obtained by isotopic methods on surrounding thuya and mòbergs and tephrostratigraphy allow to also attribute indirectly an Eemian age (MIS 5e) to this formation (Table 1), as the dating of Galtalækur lava in unit R-C4 failed (argon degassing) due to argon escape related to the rock crystallinity.

\section{Stratigraphic setting of the Rangá Formation Regional setting}

South-central Iceland is a wide depression limited by two tectono-volcanic zones: the South Volcanic Zone (SVZ) and the most active part, the East Volcanic Zone (EVZ, Fig. 1A). It includes among others the Hekla, Katla, Torfa, and Tindafell volcanoes. This depression is one of the main outlets of the Icelandic glaciers, Vatnajökull, Hofsjökull, and Langjökull. The central plain is formed by a complex sandur related to the Ytrí Rangá, Pjórsá, and Hvítá rivers (Fig. 1B). It is regularly scoured by Late Glacial - Holocene jökulhlaups or flash floods, often triggered by subglacial volcanic activity (Björnsson 2002).

During the last deglaciation a step-like glacial retreat left a succession of terminal moraines, attributed to the Younger Dryas or to the Preboreal glacial advances (Geirsdóttir et al. 1997; Ingólfsson et al. 2009). During this period, outlet glaciers from the Weichselian ice sheet calved in a wide bay. The deposits associated with these advances are interstratified with jökulhlaup deposits, basaltic tephra, and marine deposits. The highest marine 
Van Vliet-Lanoë, B., Schneider, J.L., Guðrmundsson, Á., Guillou, H., Nomade, S., Chazot, G., Liorziou, C., Guégan, S., 2017. Eemian estuarine record forced by glacio-isostasy (S Iceland) link with Greenland and deep sea records. Can. J. Earth Sc. In press

doi.org/10.1139/cjes-2017-0126

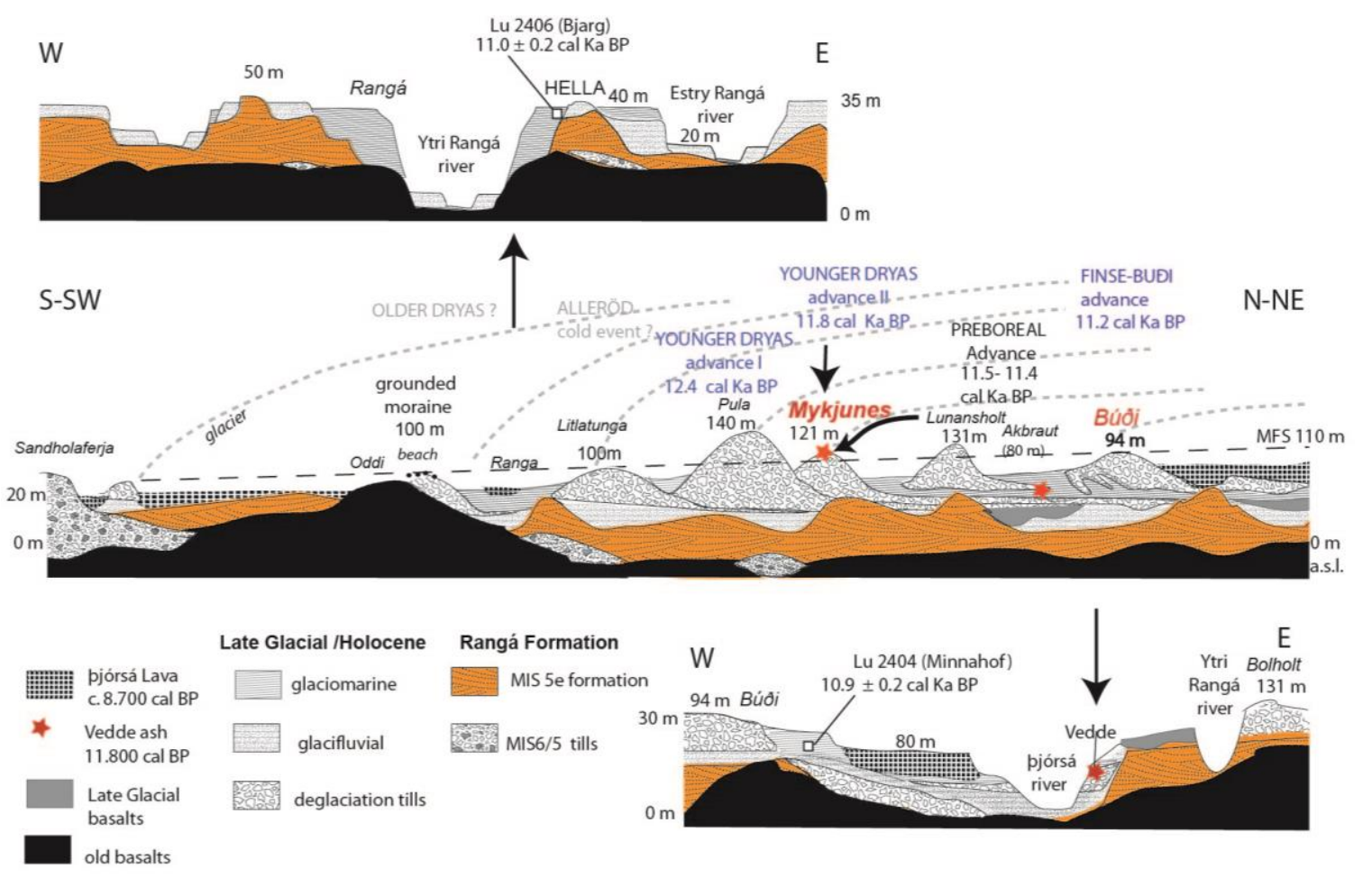

Fig. 2. Transects in the sandur of the Pjórsá and Rangá lower valleys.

TABLE 1: Dating bracketing the Rangá Formation and regional morphology.

\begin{tabular}{|c|c|c|c|c|}
\hline Site & Sample ID & $\begin{array}{l}\text { Age } \pm 2 \sigma \\
\text { Ka }\end{array}$ & Method & Reference \\
\hline \multicolumn{5}{|l|}{ Rangá and Post-Rangá dating } \\
\hline $\begin{array}{l}\text { Skardsengi,(Morđudalur, NVZ) } \\
\text { Basalt above the Syđra / Ranga fm }\end{array}$ & $\begin{array}{l}\text { ISLN-17 } \\
\text { aerial lava }\end{array}$ & $81 \pm 9$ & $\mathrm{~K}-\mathrm{Ar}$ & Guillou et al. 2010 \\
\hline $\begin{array}{l}\text { Sandfell Móberg (Halslón) Recent } \\
\text { dyke }\end{array}$ & $\begin{array}{l}\text { KH1 } \\
\text { subglacial }\end{array}$ & $103 \pm 17$ & ${ }^{39} \mathrm{Ar} /{ }^{40} \mathrm{Ar}$ & Helgason and Duncan 2003 \\
\hline Rauðafell Móberg & $\begin{array}{l}\text { ISLN-71 } \\
\text { subglacial }\end{array}$ & $104 \pm 31$ & $\mathrm{~K}-\mathrm{Ar}$ & Guillou, this paper (Supl. 3) \\
\hline Petursey Móberg & $\begin{array}{l}\text { ISLN-81 } \\
\text { subglacial }\end{array}$ & $113 \pm 5$ & $\mathrm{~K}-\mathrm{Ar}$ & Guillou, this paper (Supl. 3) \\
\hline Ljósufjöll summit (Snæfellness) & $\begin{array}{l}02 / 080 \\
\text { Unit } 4, \text { subglacial }\end{array}$ & $113 \pm 6$ & ${ }^{39} \mathrm{Ar} /{ }^{40} \mathrm{Ar}$ & Flude et al. 2008 \\
\hline Kerlingarfjöll (Snækollur) & $\begin{array}{l}\text { ISLN-95 } \\
\text { aerial lava }\end{array}$ & $116 \pm 3$ & $\mathrm{~K}-\mathrm{Ar}$ & Guillou, this paper (Supl. 3) \\
\hline $\begin{array}{l}\begin{array}{l}\text { Hlöðufell móberg } \\
\text { (South Langjökull) }\end{array} \\
\end{array}$ & $\begin{array}{l}\text { ISLN-73 } \\
\text { subglacial } \\
\end{array}$ & $118,7 \pm 17$ & $\mathrm{~K}-\mathrm{Ar}$ & Guillou, this paper (Supl. 3) \\
\hline \multicolumn{5}{|l|}{ Pre-Ranga dating } \\
\hline Ljósufjöll summit (Snæfellness) & $\begin{array}{l}\text { 02/102, L13, U5, } \\
\text { subglacial }\end{array}$ & $129 \pm 16$ & ${ }^{39} \mathrm{Ar} /{ }^{40} \mathrm{Ar}$ & Flude et al. 2008 \\
\hline $\begin{array}{l}\text { Ljósufjöll (Nykuhraum, } \\
\text { Snæfellness) }\end{array}$ & $\begin{array}{l}\text { ISLN-99 } \\
\text { aerial lava }\end{array}$ & $129 \pm 4$ & $\mathrm{~K}-\mathrm{Ar}$ & Guillou, this paper (Supl. 3) \\
\hline Prestahnúkur (Langjökull) & subglacial, & $132 \pm 19$ & ${ }^{39} \mathrm{Ar} /{ }^{40} \mathrm{Ar}$ & Clay et al., 2015 \\
\hline $\begin{array}{l}\text { Ljósufjöll (Gerðuberg, } \\
\text { Snæfellness) }\end{array}$ & $\begin{array}{l}\text { ISLN-46 } \\
\text { aerial lava }\end{array}$ & $135 \pm 5$ & $\mathrm{~K}-\mathrm{Ar}$ & Guillou, this paper (Supl. 3) \\
\hline Litlilækur Ranga & $\begin{array}{l}\text { ISLN-84 } \\
\text { aerial lava }\end{array}$ & $155 \pm 25$ & $\mathrm{~K}-\mathrm{Ar}$ & Guillou, this paper (Supl. 3) \\
\hline
\end{tabular}

The zone is crossed from west to east by a very active seismic zone, the South Icelandic Seismic Zone (SISZ, Fig. 1A; Einarsson and Eiríksson 1982). 
Van Vliet-Lanoë, B., Schneider, J.L., Guðmundsson, Á., Guillou, H., Nomade, S., Chazot, G., Liorziou, C., Guégan, S., 2017. Eemian estuarine record forced by glacio-isostasy (S Iceland) link with Greenland and deep sea records. Can. J. Earth Sc. In press

doi.org/10.1139/cjes-2017-0126

\section{Sedimentary setting}

For practical reasons, the sedimentary record in this region will be subdivided into several members. Member $\mathrm{R}$ A concerns the oldest features and member R-B a glacio-volcanic complex with a 40K-40Ar age close to ca. 155 Ka (Table 1; File S31); member R-C represents the Rangá Formation itself, ca. 129-110 Ka BP in age; members R-D, R-E, and R-F cover the full Glacial (Weichselian), the Late Glacial, and the Holocene. The old units of members R-A and R-B are usually strongly lithified and dark grey in color. Holocene and Late Glacial deposits are usually dark grey in color, with a low hyaloclastite content, unconsolidated, rarely faulted, and discrete in space. Conversely, member R-C, the Rangá Formation sensu-stricto,mostly consists of consolidated dark-brown orange to yellowish-grey hyaloclastite sands, consolidation resulting from smectite neosynthesis (Wada et al. 1992). Post-depositional transtensive tectonism locally deforms the Rangá Formation, as also the Holocene pjórsá lava. Dynamic glacial processes commonly fault and shear the deposits older than the Holocene. The detailed description is available in File S11.

\section{Results: the Rangá Formation}

\section{Previous observations}

This unit has never been described in itself. The only observations on this material concern "loesses" cropping out along the Estry Rangá River (Einarsson 1994, fig. 20-6). We shall see that these are really aeolian, which correspond to our unit R-C5 (Fig. 3B). In the outcrops of the Estry Rangá River, east of Hella, the "basal" root tracks correspond to tidal burrows (lugworms and crabs, see File S11) followed by rust-stained rooting of a pseudogley soil. This consolidated sediment does not contain faunal remains neither molds nor shells. Stratified soft sandy marine beds were dated as Holocene on shells near Hella (Bjarg, $11.018 \pm 0.225$ cal. Ka BP; Hjartarson and Ingólfsson 1988; Fig. 2), laterally $200 \mathrm{~m}$ from the consolidated formation (Fig. 2). These dated beds are in fact deposited in a valley incised into the consolidated Rangá Formation.

\section{Ytrí Rangá valley's outcrops: synthetic facies description and interpretation}

This sedimentary formation mostly crops out along the Tjorsa River, from the Burfell to the shoreline (Figs. 1B, 3, and 4), filling up most of the Ytri Ranga valley (Fig. 4A). The analysis of the stratigraphy was facilitated by the incision from Late Glacial - Holocene jokulhlaups, and by the preservation of sediments beneath the Tjorsa and probably Late Glacial lavas, south of the Burfell (Late Glacial age estimate of 10-15 Ka, H. Guillou, unpublished). Most Holocene and Late Glacial deposits rest unconformably on the Ranga Formation (Fig. 3).

\section{Member $R$-A}

This member corresponds to very old consolidated tills and basaltic lava flows, the oldest basalts that are incised, glacially polished, and unconformably covered by matrix-supported tills and (or) by other younger deposits of the Rangá Formation. It mostly crops out on the left bank of the upper Ytrí Rangá valley.

\section{Member $R-B$}

This member is recorded in the upper Ytrí Rangá valley, at Ófærugil (Fig. 5), and it is subdivided into two units, R-B1 and R-B2. Unit R-B1 is constituted of highly consolidated, stacked basal tills and old lava flows, which are locally faulted. They represent old glaciations and are lately incised to the present valley floor by subsequent jökulhlaup activity. This first incision is invaded by subglacial pillow lava flows later buried by unit R-B2. Subunit R-B2a is a stratified prograding fan. It is further followed by a slurry flow reworking a phreatomagmatic advantice cone (Carey et al. 2000) of the Hekla volcanic system (Ófær 1; File S21; Norðubjallar ridge, $500 \mathrm{~m}$ a.s.l., Fig. 4). This cone was emerging from theglacier at the time of its activity and was further destabilized by glacier melt. This mass flow penetrated into a lake. It reached Galtalækur some $10 \mathrm{~km}$ downstream, $100 \mathrm{~m}$ lower in altitude (Fig. 6). It is deformed by ductile normal faults, pasted by silts, probably related to the melting of buried ice. This subunit is truncated by subunit R-B2b, a coarsely stratified diamicton with dropstones, recording a brief glacial re-advance, damming a subglacial lake. The sedimentation further evolved aerially as subunit R$\mathrm{B} 2 \mathrm{c}$, in the form of a proximal delta evolving into a mostly distal episode (varva-like rhythmites, without 
Van Vliet-Lanoë, B., Schneider, J.L., Guðrmundsson, Á., Guillou, H., Nomade, S., Chazot, G., Liorziou, C., Guégan, S., 2017. Eemian estuarine record forced by glacio-isostasy (S Iceland) link with Greenland and deep sea records. Can. J. Earth Sc. In press

doi.org/10.1139/cjes-2017-0126

dropstones). It represents a major interstadial within MIS 6. A final glacial advance weakly deformed the rhythmites, suggesting the impact of a cold-based glacier. Finally, it is followed by renewed jökulhlaup activity. Silty rhythmites of unit R-B3 are preserved at Næfurholt, in juxtaglacial position. It represents a deglaciation deposit, late MIS6 in age. Old residual moraines are observed cropping out in the landscape (Fig. 4), often glacially abraded, forming a drowned relief as at Svinhagí, a pulse of a late glacial advance. Downstream, they occur locally along the presentday estuary of the Pjórsá River at Hálur and Sandhólaferja (Figs. 1B and 2), at +5 $\mathrm{m}$ a.s.l. RB unit represents a complex pulsed advance, including an interstadial, and the retreat of a glacial tongue constrained between the Hekla and the Búrfell. The top of this outcrop is eroded by unit R-C4.

\section{Member R-C}

This member is the main and most complex interval of the Rangá Formation with a thickness of $30 \mathrm{~m}$ (on average). It mainly consists of consolidated dark-brown orange to yellowish-grey hyaloclastitic

fluvial and estuarine sands. Post-depositional tectonic and dynamic glacial processes commonly fault the deposits. The deposits spread irregularly within the landscape and emplaced within channeled incisions. Member $\mathrm{R}-\mathrm{C}$ is formed by six superimposed units. The powerful erosion along the pjórsá River has limited its preservation to the lowermost units (R-C1 to R-C3).

\section{Unit R-C1}

This unit reworks brown basaltic hydroclastic particles, mostly derived from the volcanoclastic material of unit R-B2 in the middle Ytrí Rangá valley and from hyaloclastites in the Pjórsá valley. Its base at Ófærugil is erosive on an already lithified subunit R-B2a. In the Pjórsá valley, down of the Búrfell, subunit R-C1a is about $3 \mathrm{~m}$ thick and consists of coarse grey sand with fine cross stratified gravel layers forming channel and troughs prograding to the northwest. It ends with a splay of coarser gravels to the top. In the middle Pjórsá valley, at Lambagí, it is interrupted by rafts of cobbles and 2D dunes. It is further deeply incised in channels by unit R-C2. The most complete sections are observed in the middle Ytrí Rangá valley in the Örlygsstaðamelar, especially close to Svinhagi and Heiðarbrekka (Fig. 5). Subunit R-C1a is, in the Ytrí Rangá valley, mostly reworked from unit R-B2 and emplaced in both subaerial and subaqueous settings, with deep basal incision related with jökulhlaup erosion. Its base is $10-15 \mathrm{~m}$ thick in Svinhagí and consists of stratified coarse layers characterized by reverse or symmetric graded imbricated particles, interpreted as hyperpycnal flow deposits (see File S11). Subunit R-C1a was very likely fed by glaciofluvial processes, leading to similar facies as described in proglacial lakes (Eyles et al. 1987) without evidence of marine influence. It seems to correspond to the bottom sets and (or) the foresets of a delta, with pulsed deposits that also spread to the northwest along the foot of the Búrfell. It is fed by recurrent jökulhlaups and with a position of the water level close to $140 \mathrm{~m}$ a.s.l. Subunit R-C1b consists of sandur-type deposits (Maizels 1997), only preserved upstream. It reworks rounded Hekla pumice from an old deposit, located northeast of the Búrfell, that yielded $419 \pm 17 \mathrm{Ka}$ in age by 40Ar/39Ar dating (ISLN-112, Files S21 and S31). Synsedimentary water-escape structures affect the whole unit.

\section{Unit R-C2}

This unit corresponds to sandy channel deposits within a braided fluvial network, usually $5 \mathrm{~m}$ thick, with a clearly erosive base, but it may reach up to $60 \mathrm{~m}$ in thickness on the sides of the Skarðsfjall or along the Pjórsá River. The facies of the top of this unit is very similar to the deposit preserved in the canyon above the Stöng archeological site (Figs. 1B and 4). At Næfurholt, it crops out at least up to $140 \mathrm{~m}$ a.s.l. Subunit R-C2 corresponds upstream to fluvial deposits that evolve into coastal fluvial deposits downstream of Galtalækur. There, it presents some marine influence (thin silty clay drapes regularly interstratified within the prograding 3D sandy bars; Allen 1982) downstream at least from Lambhagí (130 m a.s.l.) or in front of Búrfellstöð power plant, under a microtidal regime. These coastal fluvial deposits suggest a progradation of tidal deltaic bodies in a riverdominated estuary (Figs. 4 and 6) as fluvial deposits dominate. This progradation could correspond to an early regression or to the erosion of the inland in connection to the glacial rebound. Convolutes, water-escape structures, and faulting are also present. 
Van Vliet-Lanoë, B., Schneider, J.L., Guðrmundsson, Á., Guillou, H., Nomade, S., Chazot, G., Liorziou, C., Guégan, S., 2017. Eemian estuarine record forced by glacio-isostasy (S Iceland) link with Greenland and deep sea records. Can. J. Earth Sc. In press

doi.org/10.1139/cjes-2017-0126

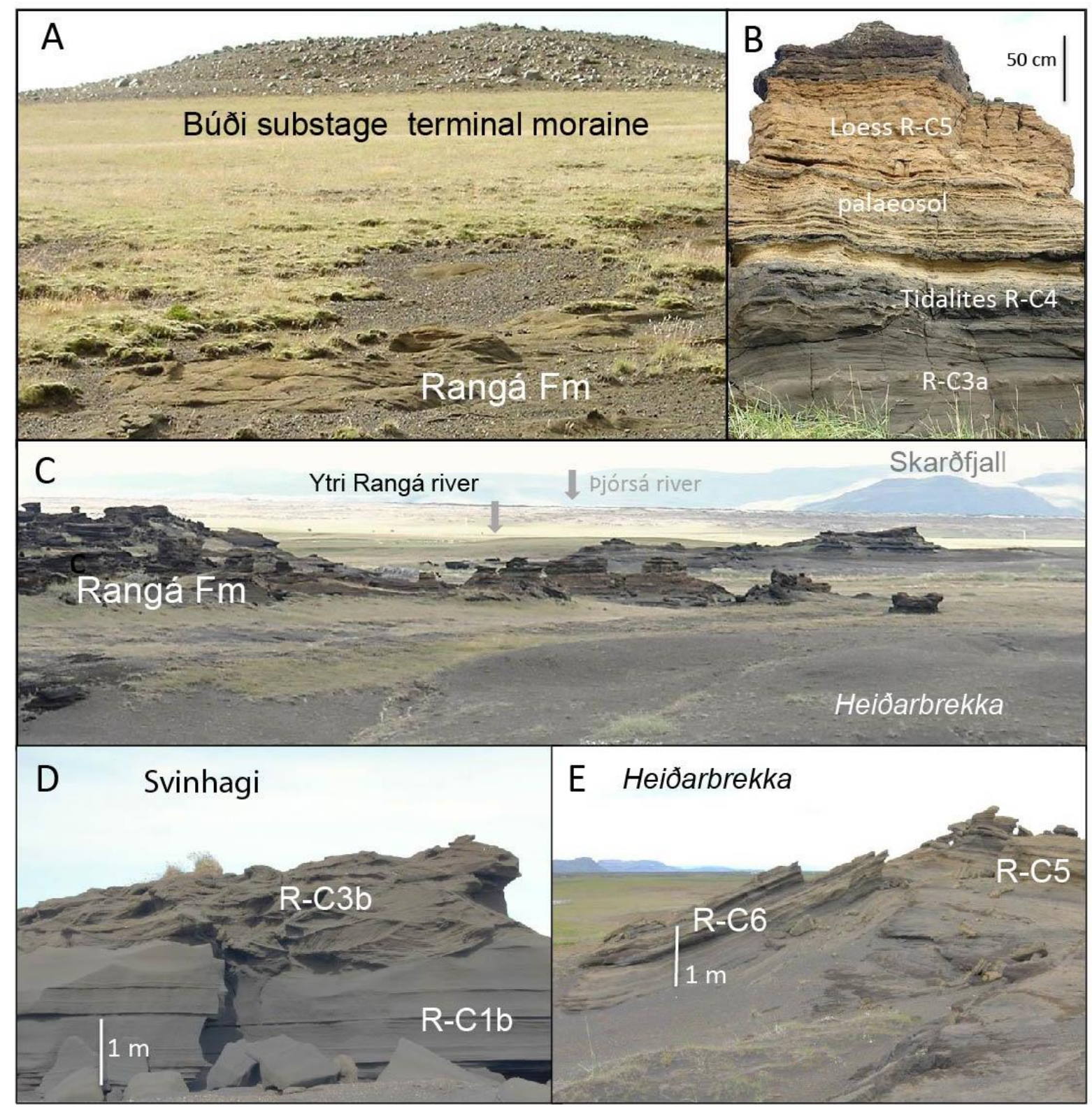

Fig. 3. (A) Rangá Formation below the Búði terminal moraine south of Heiðarbrekka. (B) Residual pinnacle with units $R$-C4 and R-C5 (loess) at Heiðarbrekka with a level of co-seismic deformation between units $R-C 3 a$ and $R$-C4. (C) Global view of the Heiðarbrekka outcrop: unit R-C6 is the channelized top facies. Note the common pinnacle morphology. (D) Erosional scour at the base of unit R-C3b at Svinhagi. (E) Angular discontinuity between units R-C5 and R-C6 (top facies) at Heiðarbrekka.

Unit R-C3

This unit consists of centimeter laminated medium sands, subdivided laterally into the two subunits R-C3a and $\mathrm{R}-\mathrm{C} 3 \mathrm{~b}$. Both subunits are never in superposition. Their base is strongly erosive.Unit R-C3 corresponds to coastal sand bars and lateral braided shallow tidal channels (subunit R-C3a: with mud drapes and few bioturbations). Reworked mud clasts intercalated within muddraped laminae are common. Subunit R-C3a is 2-3 m thick, open estuarine slikke fed by lateral river fans. It reworks a large amount of phreatomagmatic tephra from the Grimsvötn volcano (Grim 1, File S21; Fig. 9), splayed above 70ma.s.l., mostly in the Ytrí Rangá valley, from Heiðarbrekka to Kirkjubær (Figs. 1B and 7), very often deformed by load casts and water-escape pipes. It is up to $3 \mathrm{~m}$ thick at Kirkjubær where it is deformed by plurimetric involutions (giant load casts). Floated lapilli end 
Van Vliet-Lanoë, B., Schneider, J.L., Guðxmundsson, Á., Guillou, H., Nomade, S., Chazot, G., Liorziou, C., Guégan, S., 2017. Eemian estuarine record forced by glacio-isostasy (S Iceland) link with Greenland and deep sea records. Can. J. Earth Sc. In press

doi.org/10.1139/cjes-2017-0126

the deposit. Its specific location suggests a widespread deposition probably transported from the Tungnaá River by jökulhlaups, sometimes directly on units R-C1 or R-C2. Tectonism and co-seismic deformations were observed here. Subunit R-C3b represents a few main channels, which constitute the best-preserved and most common facies of the Rangá Formation. It is commonly $3 \mathrm{~m}$ thick with very well-developed dissymmetric cross bedding (TCS vortex ripples; Dumas and Arnott 2006) and corresponds probably to the bottom of an inlet affected by tidal channels and storms with subaqueous current passing diagonally over the channel (McKee 1957). It crops out from 220ma.s.l. in the upper Ytrí Rangá valley (Ófærugil) down to Svinagí (Figs. 4B and 5C) and from140 m a.s.l. in the Pjórsá valley (Lambhagí). Bioturbation is totally absent.

Subunit R-C3b corresponds most probably to a seaward accreting tidal-bar complex on a delta in a V-like estuary (Fig. 1B). It is under the influence of recurrent autumn-winter storminess (northeast winds, Swift and Nummedal 1987) with resulting enhanced ebb currents (Johnson 1977). It reworks relatively quieter sandy deposits (river-dominated fine sand deposition during the snowmelt season). As this regressive system is $5 \mathrm{~m}$ thick in maximum, the duration of the setting of this facies was probably ca. a millennium, compared to the observations by Johnson (1977).

\section{Unit R-C4}

This unit crops out from Næfurholt at $160 \mathrm{~m}$ a.s.1. to Heiðarbrekka (Figs. 5B, 5C, and 6). It is not preserved along the Pjórsá River, excepted on the Skarðsfjall. Hereto, tectonism and coseismic deformation were observed. The base is irregular and clear, often deformed by load casts penetrating the top of subunit R-C3a. Unit R-C4 corresponds to subhorizontal to slightly wavy centimeter stratified sandy silt, forming locally low relief on the side of channels, sometime in shallow channels with rhythmic sedimentation (fine sand alternating with millimeter silty to clayey very fine sands) with centimeter-sized bioturbations (burrows of various sizes, few grass roots; see File S11), pasted with thin silty clay drapes that are present within the fine-grained layers. Herringbone tidal laminations are observed in some levels. Some diatomite layers occur very locally in shallow ponds, lateral to the channels, with frost traces in the upper part. This late tidal sedimentation represents at least $1 \mathrm{~m}$ of deposits. Unit R-C4 evolved upwards to a vegetated marsh under tidal influence (internal estuary).

As a whole, unit R-C4 is interpreted as the witness of a prograding coastal sedimentation evolving into a salt marsh. It seems diachronic from north to south, following a regressive trend. A thin $(<2 \mathrm{~m})$ but extensive basaltic lava flow from the Hekla volcano (File S21) spreads on an internal erosion surface in unit R-C4 close to Galtalækur (120 m a.s.l.). After two thin basaltic tephra deposited originated from the Grimsvötn (Grim 2) and Hekla volcanoes (Hk 2, Fig. 8). At Heiðarbrekka, Hk 2 and Grim 2

tephra also crop out, separated by five very fine basaltic tephra layers (Fig. 8).

\section{Unit R-C5}

These deposits are particularly well developed from Heiðarbrekka to Næfurholt cropping as residual pillars along the Ytrí Rangá River. Their base is erosive. They are not preserved along the Pjórsá River, excepted at Skarðsfjall. Subunit R-C5a weathered the top of unit R-C4 to a hydromorphic palaeosoil with rhizomorph concretions at Heiðarbrekka, or to an orange andosol on higher ground (Figs. 4B and 6). Subunit R-C5b consists, at Heiðarbrekka, of $1.50 \mathrm{~m}$ of thick rather regularly laminated loess, the stratification being often subhorizontal to wavy, adapting to the former marsh palaeotopography. It includes a set of 20 thin basaltic tephra layers separated by $2 \mathrm{~cm}$ loess' layers and recorded in three sets. It includes two Grimsvötn and three Hekla basaltic tephra layers (3-5 cm thick). Subunit R-C5c evolves back to tidalites to the top, including the last tephra of Hekla origin, further weathered to a pseudogley. Unit R-C5 records a general and total emersion with loess deposition with frequent tephra layers and some glaciofluvial incursions in low topographic settings. Complete emersion is achieved and the return to tidalite facies announces the next transgression. 
Van Vliet-Lanoë, B., Schneider, J.L., Guðrmundsson, Á., Guillou, H., Nomade, S., Chazot, G., Liorziou, C., Guégan, S., 2017. Eemian estuarine record forced by glacio-isostasy (S Iceland) link with Greenland and deep sea records. Can. J. Earth Sc. In press

doi.org/10.1139/cjes-2017-0126

A

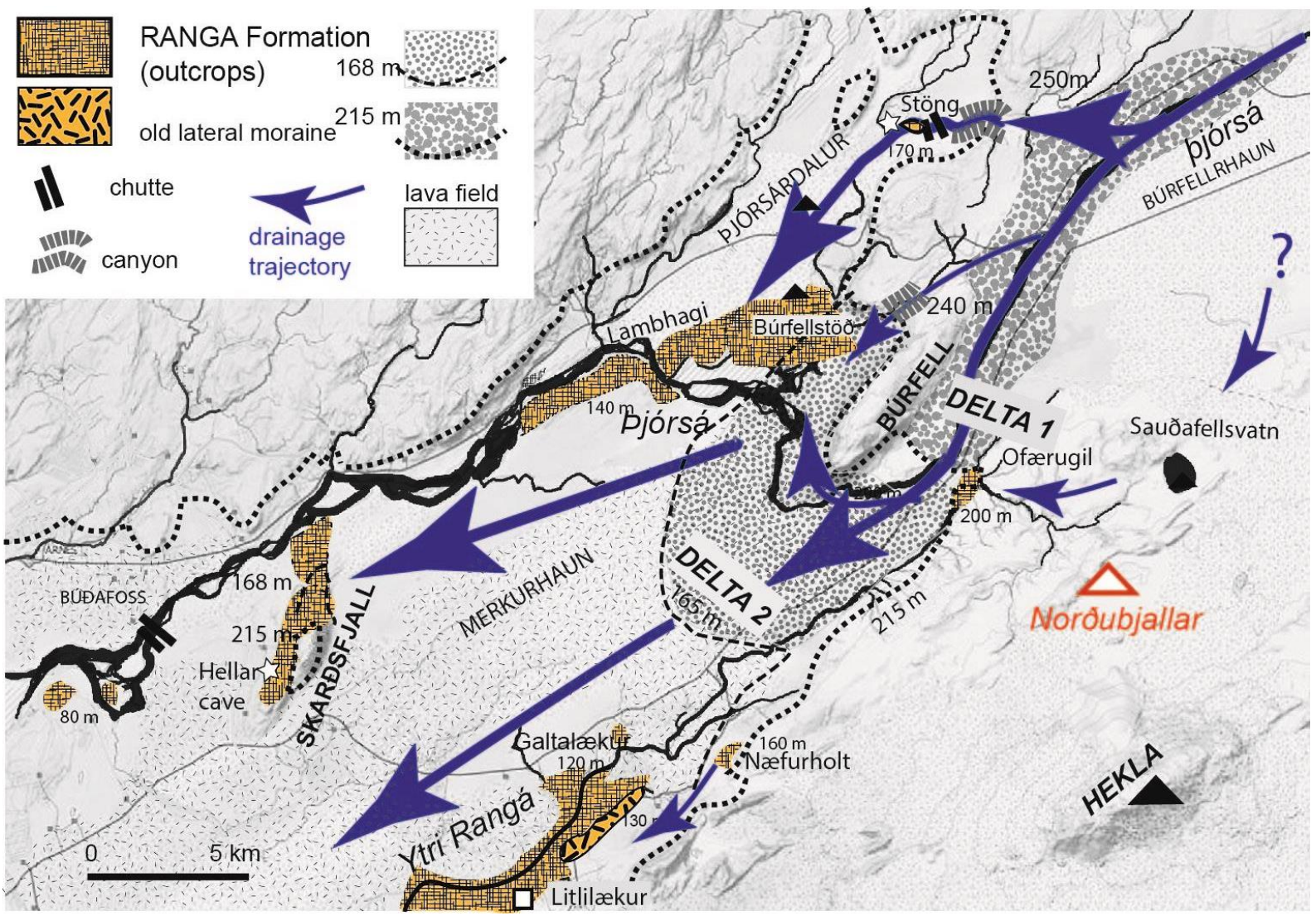

B

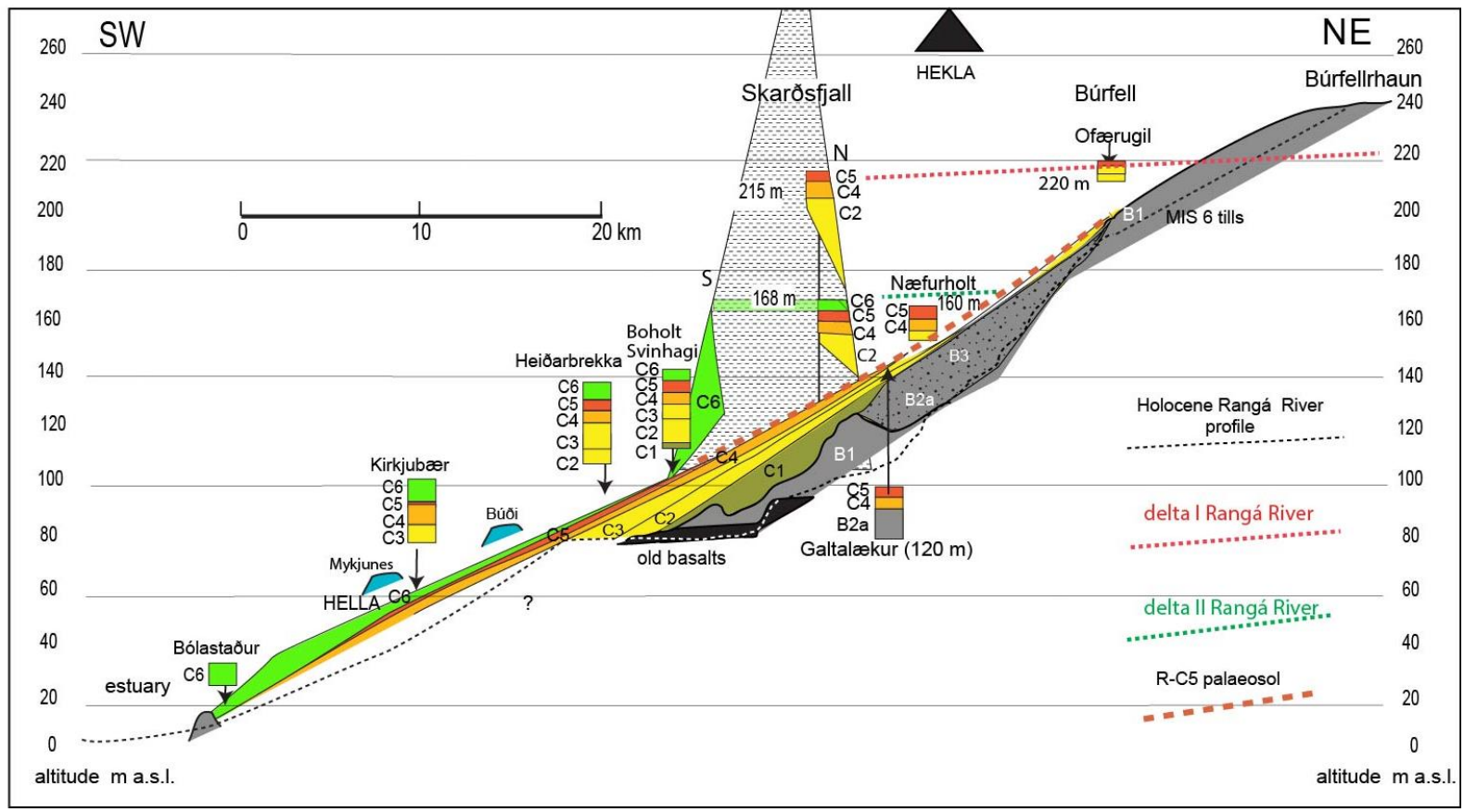

Fig. 4. (A) Map of the Rangá Formation extent southwest of the Búrfell. The arrows indicate the observed flow directions. Litlilakur is theplace for the $K-A r$ dating of lava overlapped by the Ranga Formation. (B) Longitudinal transect of the Rangá Formation, not too different from that of the present-day. Unit R-C5 (in red) traces the emersion. Unit R-C6 (in green) traces the second transgression. Late Glacial and Holocene morainic arcs are in blue. The vertical scale of the stratigraphic columns is twice these for transect. Stars indicate archeological sites. Unit labelling is simplified for space. [ 
Van Vliet-Lanoë, B., Schneider, J.L., Guðrmundsson, Á., Guillou, H., Nomade, S., Chazot, G., Liorziou, C., Guégan, S., 2017. Eemian estuarine record forced by glacio-isostasy (S Iceland) link with Greenland and deep sea records. Can. J. Earth Sc. In press

doi.org/10.1139/cjes-2017-0126

\section{Unit R-C6}

This unit is preserved in the Ytrí and Estry Rangá watersheds and below the Holocene prism of Rauðalækur River (Bolstaður, Lu 2405: $10.8 \pm 0.3$ cal. Ka BP; Hjartarson and Ingólfsson 1988). The

best outcrops occur only on a major basal discontinuity in the southern part of the Rangá Formation from Svinhagí (Fig. 4B). It is not preserved along the Pjórsá River, except on the Skarðsfjall (see further). Units R-C4 and R-C5 already formed reliefs in the Ytrí Rangá valley at that time, with evidence of syn-sedimentary faulting. Unit R-C6 consists mostly of subhorizontal coarse tidalites evolving in prograding gravelly sands in throughs (braided channels). The most common facies of the early sedimentation is similar to the top set of Gilbert delta at Bolstaður (40ma.s.1.). It is marked by tidalites, associated with a major incision, probably by jökulhlaups, followed by a return to tidal conditions (herringbone cross-stratification, tidal leading to emplacement of granule-rich layers, especially downstream of Hella (Bolstaður). Unit R-C6 records thus a renewed transgressive event, already sensible in upper unit R-C5. The top subunits mark a return to tidal conditions followed by a second emersion (pseudogley soil, loesses, and colluvium at Heiðarbrekka and Hellar cave). It reworks close to its base, a major basaltic tephra (Grim 5, Fig. 8).

\section{Uppermost outcrops.}

At Ófærugil, member R-C is only relic as the whole member only reaches $5 \mathrm{~m}$ in thickness. It is difficult to attribute a precise stratigraphic position to the different layers. The basal unit R-C1 should here consist (Fig. 5A) of openwork rounded heterometric conglomerate scouring subunits R-B2a and R-B3, probably emplaced by jökulhlaups. It is followed by horizontally stratified sands more or less channelized, including some cobbles, or erosive layers with reverse-graded cobbles in a sandy matrix, probably equating unit R-C2. The potential unit RC3-4 consists of prograding gravelly sands in throughs eroding the previous unit. It is weathered by a palaeosoil and covered by loessic deposits, the unit R-C5. Unit R-C6 has not been observed. All this suggests the accidental preservation of this unit in a depressed and protected position (the dell) of the landscape (Fig. 5A) although the facies mostly evidence rapid sedimentary transit.

\section{The Skarðsfjall outcrops -}

In the middle of the Pjórsá - Ytrí Rangá embayment, Skarðsfjall hill (Fig. 4) constituted an island within the estuary, piking at $336 \mathrm{~m}$ a.s.l. The eastern and western ends are devoid of sediment due to the erosion related to Late Glacial and Holocene jökulhlaups. Some remnants of consolidated tills are preserved to the east (Fig. 7B). The Rangá Formation seems to crop out on Skarðsfjall hill from 115 m a.s.l. with terraces. The dominant facies is unit R-C2. The highest deposits crop out from 215 to 180ma.s.l. (Fig. 7B) and correspond to tidal deposits topped with about 0.5mof R-C5 loesses. Between 180 and 168ma.s.l., the slopes are pasted by a thin and irregular layer of tidal mud. From 158 to $168 \mathrm{~m}$, the recorded facies is similar to subunit R-C4b covered with RC5 and R-C6 units. Here, unit R-C6 mostly corresponds to tidalites enriched with basaltic tephra that clearly laps on an orange andosol and loess (Fig. 7C). It attests a second highstand close to $168 \mathrm{~m}$ a.s.1. Below $158 \mathrm{~m}$, preserved deposits correspond apparently to units R-C4 and R-C2 (Fig. 5). Unit R-C3 is not recorded in the Skarðsfjall area, except in the form of enrichment in basaltic tephra on the northern face of the hill. We have thus evidences for a first highstand or maximum flooding surface (MFS1) at 215m a.s.1., $105 \mathrm{~m}$ higher in altitude than the Holocene upper marine limit (110 m a.s.l). The second highstand (MFS2) led to the development of a littoral complex, which displays tidalites topping at $168 \mathrm{~m}$ a.s.1., some 40-60 m higher than the unit R-C6 facies cropping out to the east (Heiðarbrekka and Svinhagí, Fig. 4), also enriched in basaltic tephra (Fig. 7C). The stratigraphy of Hellar cave (108ma.s.1., Fig. 4) on the southwest face of the Skarðsfjall reveals a very thick late R-C6d laminated facies (consolidated colluvium and old loesses) including the last Grimsvötn tephra (Grim 6, HC, File S21) in three massive strata. It is truncated by an erosionsurface and covered by recent loesses. These deposits trace a rapid emersion (colluvium) and ongoing aridity (loess) and are preserved in the shadowed area for jökulhlaup and glacial erosion. 
Van Vliet-Lanoë, B., Schneider, J.L., Guð̌mundsson, Á., Guillou, H., Nomade, S., Chazot, G., Liorziou, C., Guégan, S., 2017. Eemian estuarine record forced by glacio-isostasy (S Iceland) link with Greenland and deep sea records. Can. J. Earth Sc. In press

doi.org/10.1139/cjes-2017-0126
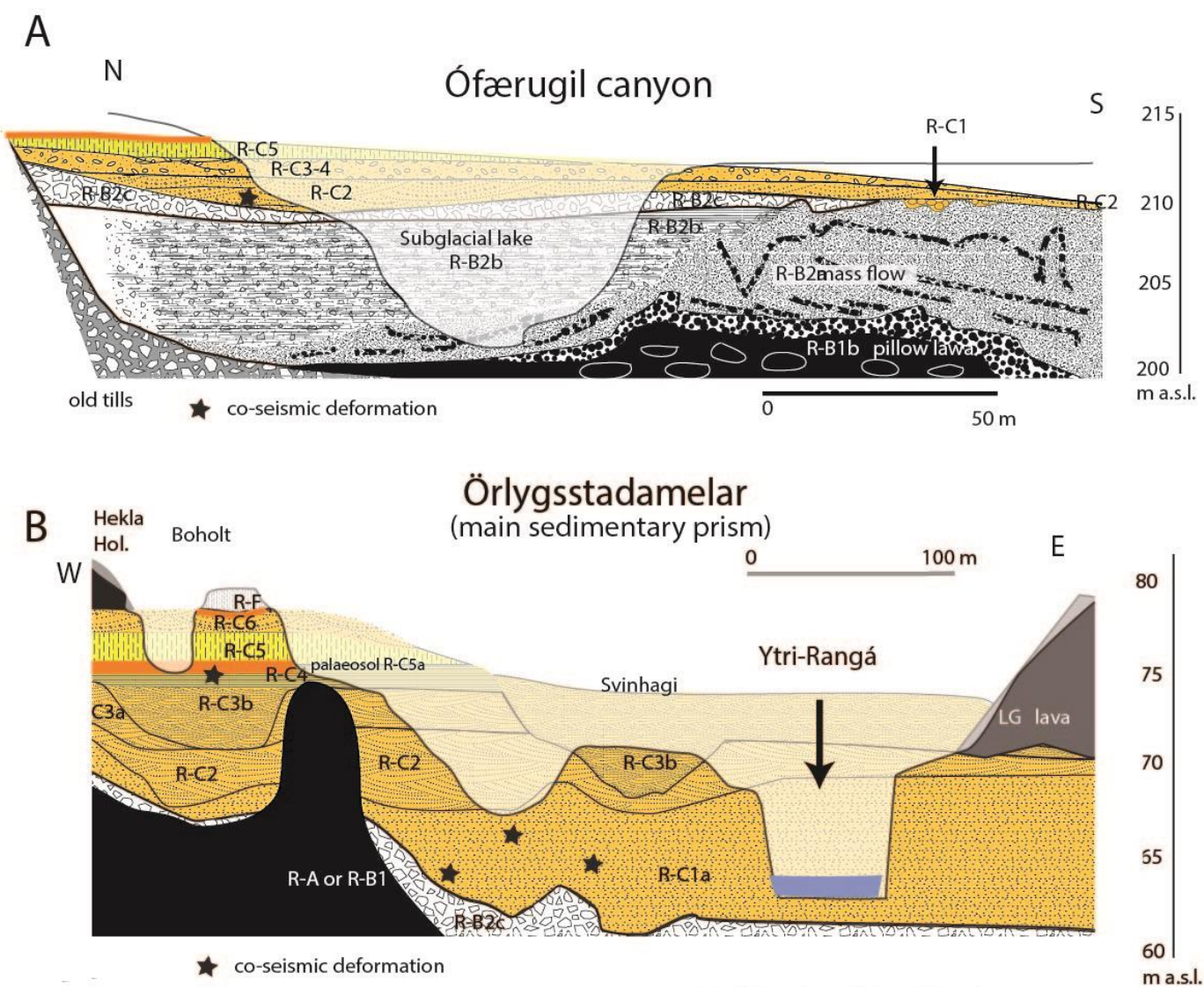

C

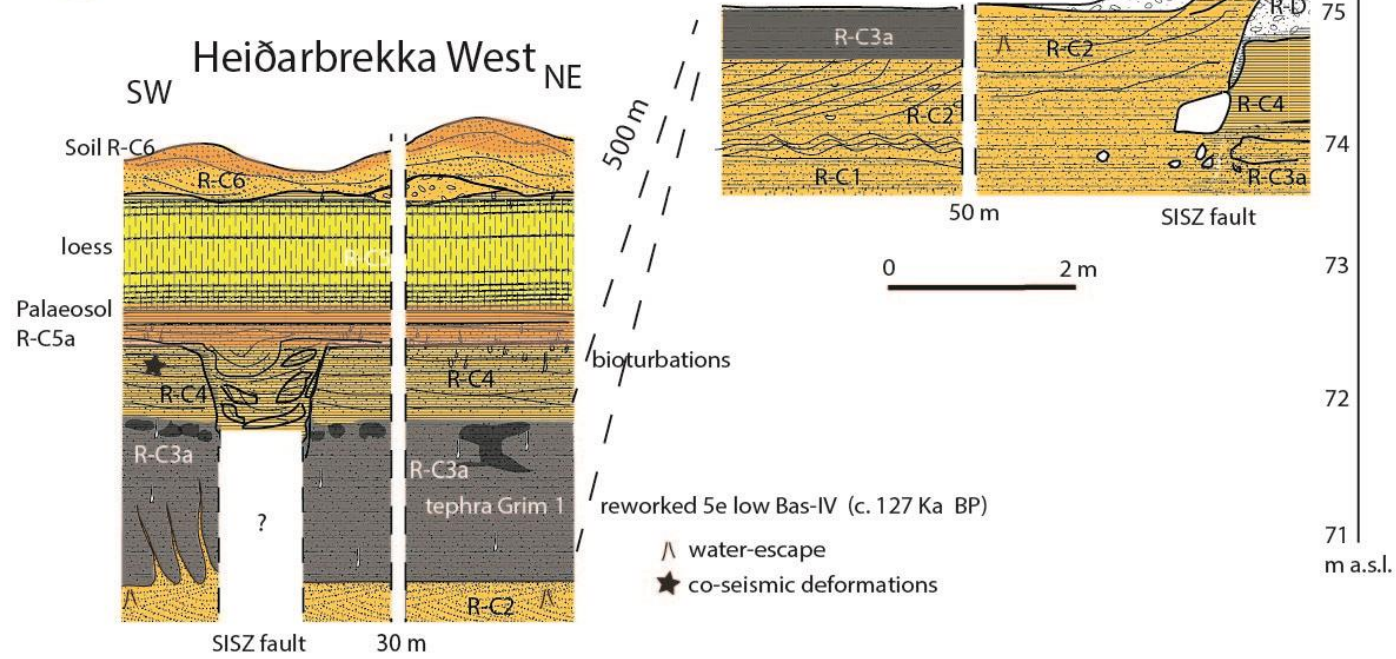

Fig. 5. Composite sections. Units $R-B$ and R-C. (A) Ófarugil canyon (parallel to the Ytrí Rangá). (B) Composite cross section of the left bank of the Ytrí Rangá River at Svinhagi. (C) Detail sections at Heiðarbrekka West and Heiðarbrekka East. Rangá Formation: light orange; loess: yellow; palaeosols: strong orange. Stars: microload cast or water-escape structure. Legend: see Fig. 6.

\section{Member R-D}

This member consists of grey glaciofluvial sand with rare cobbles and blocks, lying on units R-C3 and R-C4 at Heiðarbrekka East (Fig. 5C) or on unit R-C6 with an erosional contact. It is faulted prior to the emplacement of 
Van Vliet-Lanoë, B., Schneider, J.L., Guðrmundsson, Á., Guillou, H., Nomade, S., Chazot, G., Liorziou, C., Guégan, S., 2017. Eemian estuarine record forced by glacio-isostasy (S Iceland) link with Greenland and deep sea records. Can. J. Earth Sc. In press

doi.org/10.1139/cjes-2017-0126

member R-E. Member R-D mainly consists of remains of basal tills and has been further deformed by both glacitectonism and tectonic activity. These tills are interpreted as early Weichselian and full glacial tills but are almost rarely preserved, except as notches at $149 \mathrm{~m}$ a.s.l. on the Skarðsfjall or within glaciofluvial incisions along the Ytrí Rangá valley (Heiðarbrekka East).

\section{Members $R-E$ and $R-F$}

Termination Ia (Bølling deglaciation) does not seems to be recorded in the sector, excepted by azoic marine sands including evidence of rafted icebergs northeast of Hella, and in the sector of Lambhagí as an abrasion surface $140 \mathrm{~m}$ truncating the Rangá Formation about at the same altitude as described in western Iceland (Ingólfsson and Norðdahl 2001).

NE

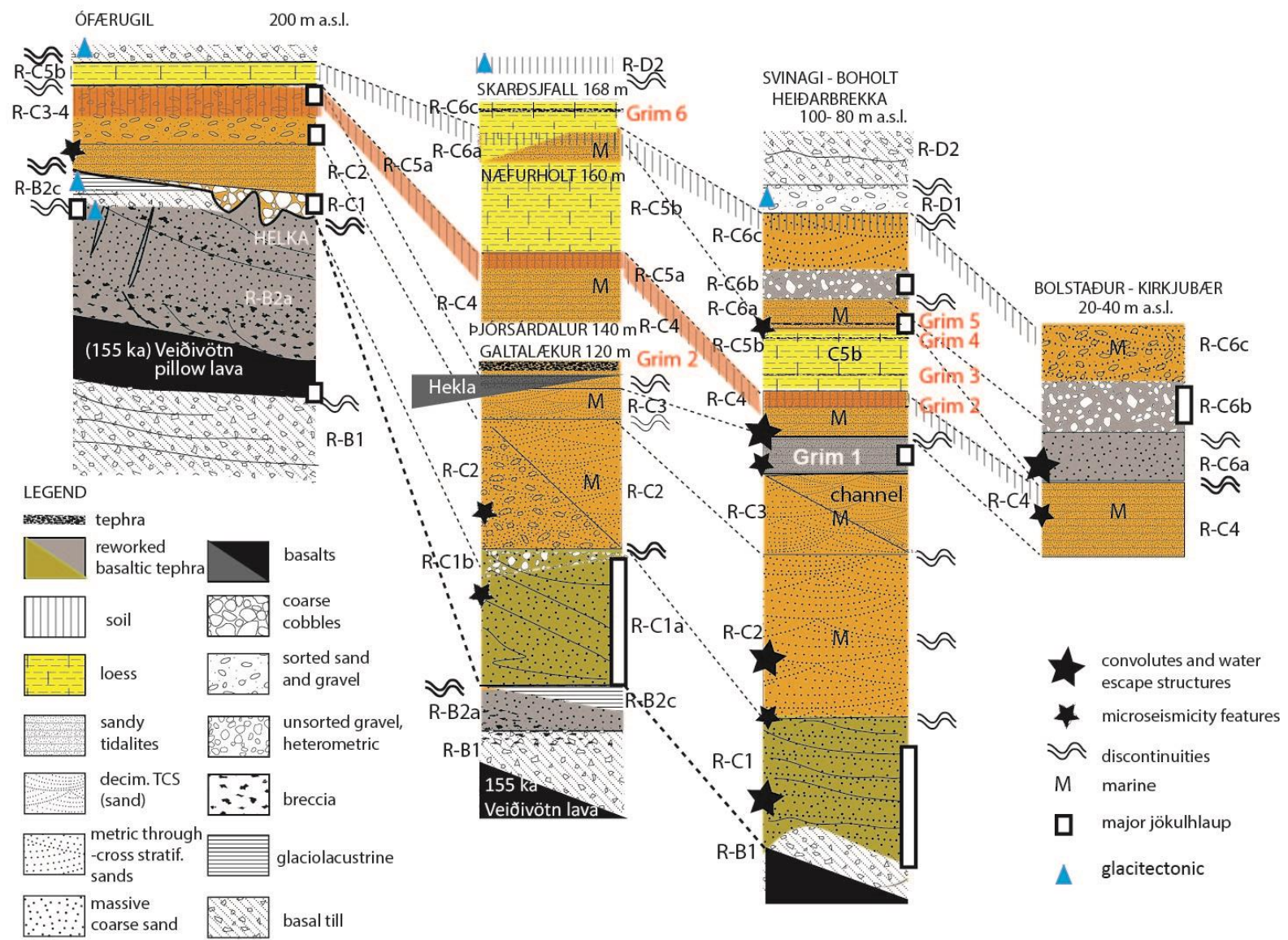

Fig. 6. Lateral stratigraphic correlations from successive composite logs from the Búrfell (Ófarugill) to the coastal sandur (not to scale). Tephra layers are indicated by bold text.

Member E: the last deglaciation (Termination Ib) The last deglaciation proceeded very fast from the Younger Dryas as also proved by the $3 \mathrm{He}$ dating of móbergs at the western edge of the central depression (Licciardi et al. 2007). The Búði morainic arcs emplaced ca. 11.2 cal. Ka BP, during the Preboreal oscillation (Geirsdóttir et al. 1997, 2000). The Pula-Mykjunes morainic system is composed of twinned arcs, older than the Búði moraine system (Fig. 2) but younger than the Rangá Formation; they are stacked on a residual hill of member R-C (unit R-C6, Fig. 7D). The summit of the youngest of the twinned arcs (Mykjunes) exposes a flow till including a bed of re-deposited Vedde Ash (Fig. 9, ca. 11.8 cal. Ka BP, Katla volcano; Guegan 2010; Lane et al. 2012; Tomlinson et al. 2012). These Pula-Mykjunes arcs correspond to the two pulses of the Younger Dryas (Fig. 2). Large sand splays are described downstream of the Búði moraines (Fig. 1B) fed by glacial rivers during the last 
Van Vliet-Lanoë, B., Schneider, J.L., Guðmundsson, Á., Guillou, H., Nomade, S., Chazot, G., Liorziou, C., Guégan, S., 2017. Eemian estuarine record forced by glacio-isostasy (S Iceland) link with Greenland and deep sea records. Can. J. Earth Sc. In press

doi.org/10.1139/cjes-2017-0126

deglaciation (Andrews et al. 2002), with most jökulhlaups events between 12 and 10 cal. Ka BP. These floods are recorded as marine turbidites units at the Younger Dryas - Preboreal transition, reworking the Vedde Ash in the lowermost unit of Lake Hestvan (marine turbidites; $57 \mathrm{~m}$ a.s.l.; Sveinbjornsdottir et al. 1998) and higher, the Saksunarvatn tephra, in full marine units (ca. 10.2 cal. Ka BP, Grimsvötn, Fig. 1B; Hannesdóttir et al. 2009; Andrews et al. 2002). These facies are visible mostly along the Estry Rangá and, locally, the Pjórsá rivers. These floods are also responsible for the incised morphology that pre and postdates (Fig. 2) the Búði morainic arcs. Member R-E ends with the Pjórsá lava emplacement around 8.7 cal. Ka BP (Hjartarson and Ingólfsson 1988).
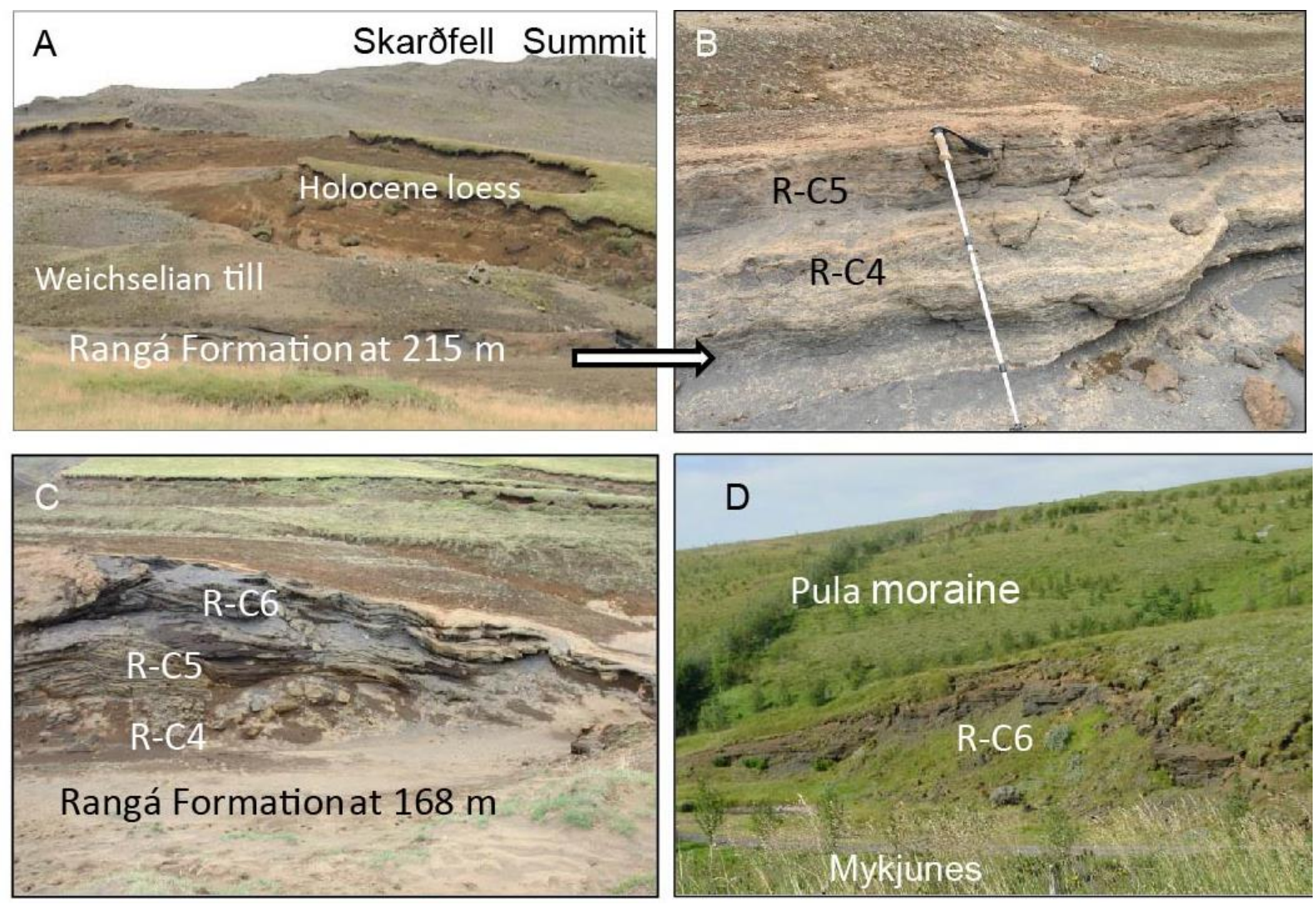

Fig. 7. (A and B) Highest level (215 $m$ a.s.l.) of the Rangá Formation on the Skarðsfjall with a detail of the section. (C) Second highstand leve (168 m a.s.l.) of the Rangá Formation on Skarðsfjall. (D) Rangá Formation (R-C6) cropping below the Pula moraine (Younger Dryas I) at Mykjunes.

Member R-F: middle and upper Holocene loesses and sand dunes Recent loesses and aeolian sands were deposited afterwards and consist in clastic unconsolidated sediments. They end the record, forming residual hills resting unconformably on the Rangá Formation. They were deposited from ca. 8.5 cal. Ka BP (Jackson et al.2005) and were subsequently mostly eroded by middle Holocene jökulhlaups, in the form of residual hills (Fig. 1B). Aeolian dunes mostly formed subsequent to the mid Holocene jökulhlaups and after the vegetation clearance by the Vikings (Arnalds et al. 1997). They are still active.

\section{Morphological anomalies}

The slope of the sedimentary prism of the Rangá Formation is not very different from the present-day valley of the Ytrí Rangá River itself (Fig. 4B). The profiles are strongly shaped by the presence of superimposed interglacial and Late Glacial to Holocene lava flows. The altitude of $215 \mathrm{~m}$ a.s.l. also corresponds to the flat, perched valley bottom of the Pjórsá River in Búrfellrhaun. This surface crops out now at $240 \mathrm{~m}$ a.s.1., a little higher than MFS1, and it is irregularly buried by at least $20 \mathrm{~m}$ of postglacial lavas (Kaldal and Vilmunðardóttir 1986). The elevation of 168 ma.s.l corresponds to a perched surface, the Merkurhaun, downstream of the Búrfell 
Van Vliet-Lanoë, B., Schneider, J.L., Guơmundsson, Á., Guillou, H., Nomade, S., Chazot, G., Liorziou, C., Guégan, S., 2017. Eemian estuarine record forced by glacio-isostasy (S Iceland) link with Greenland and deep sea records. Can. J. Earth Sc. In press

doi.org/10.1139/cjes-2017-0126

(Fig. 4A), also pasted by recent lava. It is $30 \mathrm{~m}$ higher than the dated Balling highstand (130 m; Ingólfsson and Norðdahl 2001). It thus seems plausible that the upper plain that spreads at $240 \mathrm{~m}$ in elevation might correspond to an old outwash braided plain related with the decaying ice sheet in connection with a first delta (Fig. 4A). The R-C1-C2-C3 unit complex, $30 \mathrm{~m}$ thick, seems to be the result of the first progradation of delta 1 (Fig. 4B). It occurred initially within a lake that has been further invaded by the sea. At Ófærugil, member R-C clearly lies on unit R-B2 (Fig. 5A) with an angular erosive discontinuity. Unit R-C6 results from a second progradation phase eroding and incising the older units of member R-C. Therefore, the lower surface immediately down of the Búrfell should correspond to a second outwash plain, truncating the basal complex, at 160-140 $\mathrm{m}$ in elevation, related to the post-C5 MFS, in connection with a second delta (Fig. 4A). It is further engraved by the Bølling transgression before being covered by the Pjórsá lava. Upstream of the Búrfell, the preserved deposits are discrete and patchy representing a transit of sediment or a bypass zone.

A

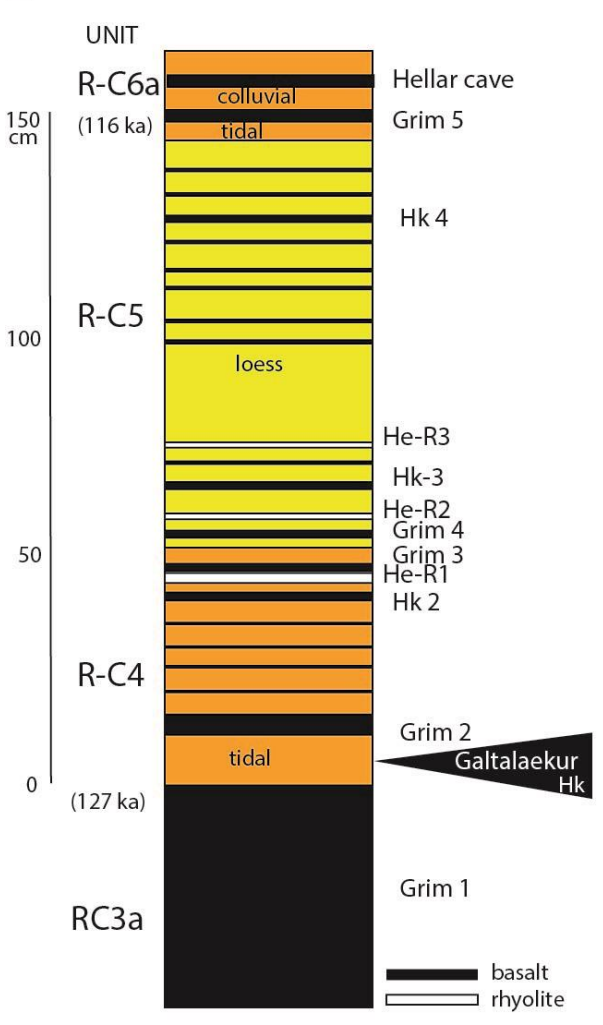

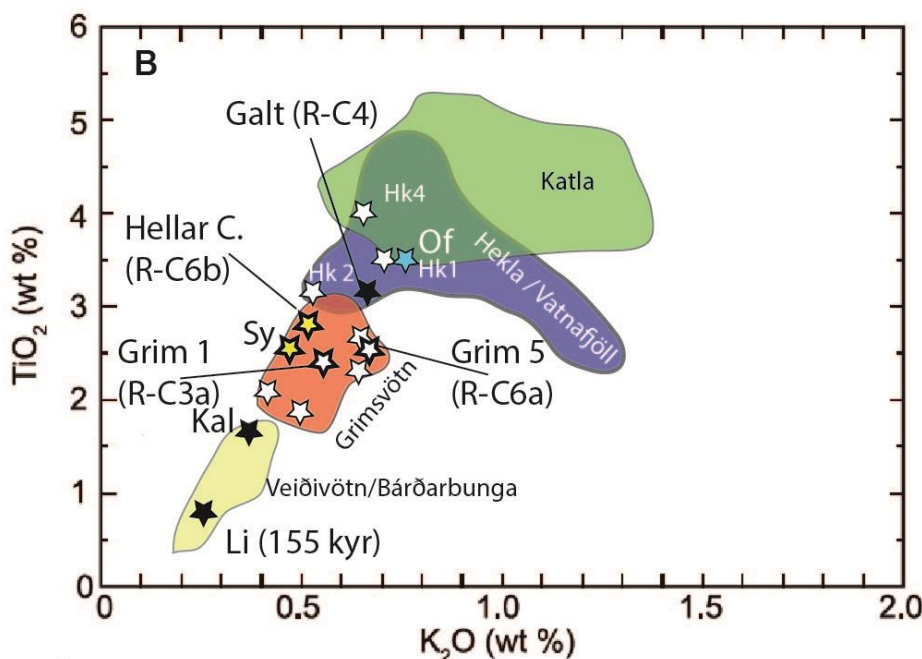

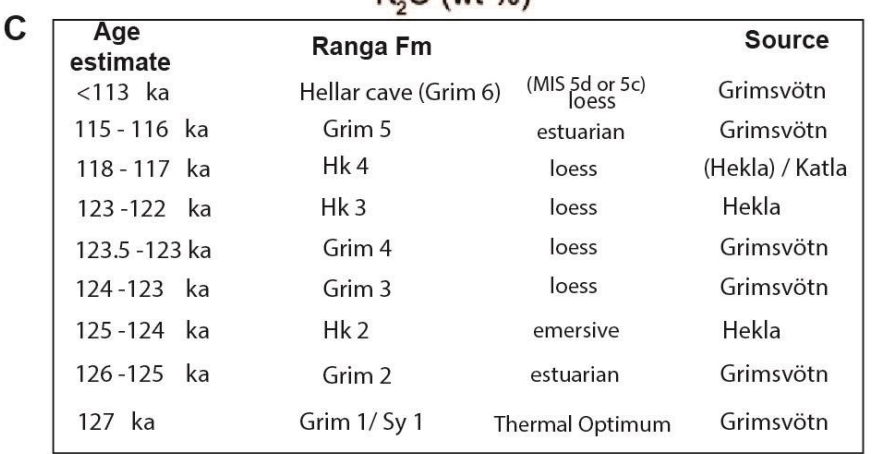

Fig. 8. Chemical analyses of the lava and tephra within the Ranga Formation. (A) Global log with the tephra location. (B and C) Analytical results of the basaltic tephra compared with the geochemical fields defined by Davies et al. 2014 (graphs and correlations; see File S21). Sy, Syðra N.; Kal, Kaldvisl dam; Of, Ófarugil; Galt, Galtalakur. Black stars: lava; white or colored stars: tephra. (B) Chemical analyses of the lava and tephra within the Rangá Formation (white text: Holocene data). Chronology for the Grimvötn tephra is extrapolated from an age regression model between the base of R-C4 (ca. $127 \mathrm{Ka})$ and the top of R-C5 (ca. $116 \mathrm{Ka}$ ), assuming a more or less regular speed of sedimentation (1.5 mm/year, Heiðarbrekka section). 
Van Vliet-Lanoë, B., Schneider, J.L., Guðrmundsson, Á., Guillou, H., Nomade, S., Chazot, G., Liorziou, C., Guégan, S., 2017. Eemian estuarine record forced by glacio-isostasy (S Iceland) link with Greenland and deep sea records. Can. J. Earth Sc. In press

doi.org/10.1139/cjes-2017-0126
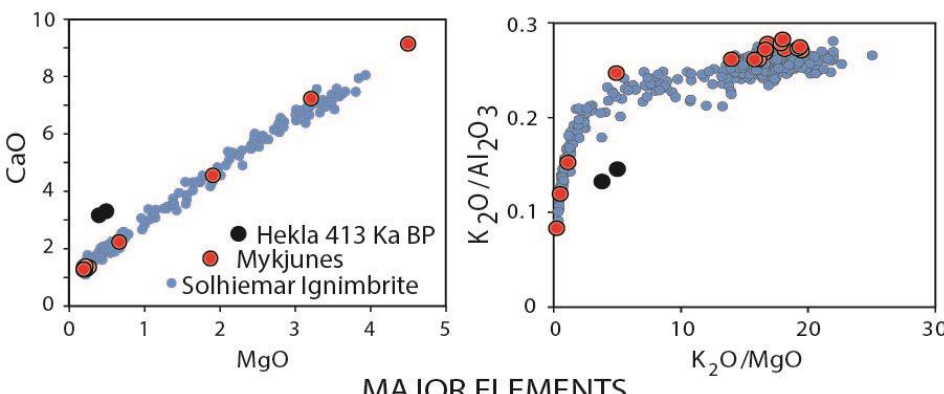

MAJOR ELEMENTS

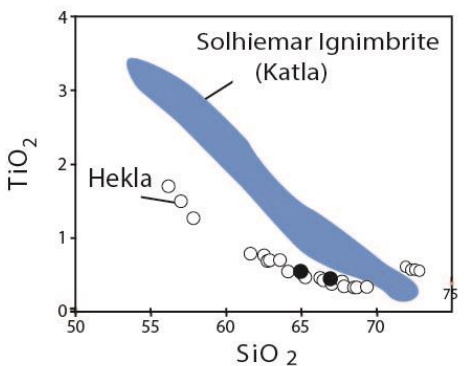

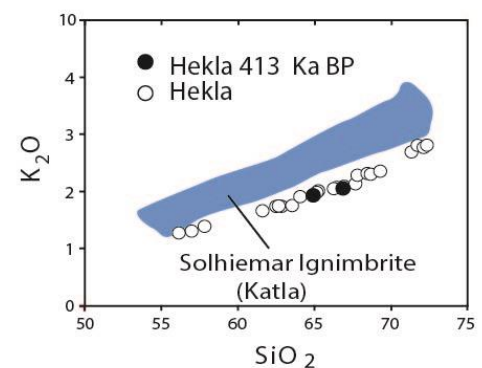

VEDDE ASH - Mykjunes

TRACE ELEMENTS

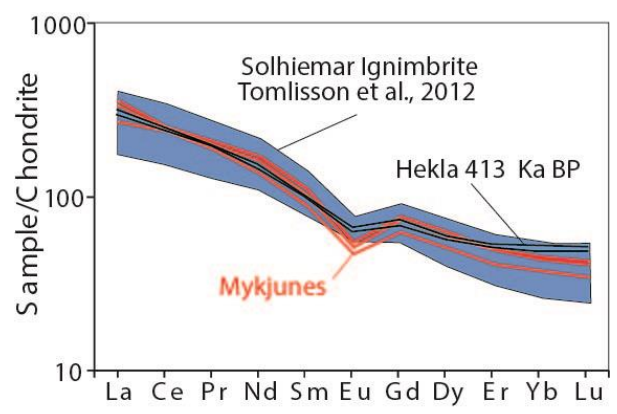

HEKLA 413 kyrs

Fig. 9. Major and rare earth element compositions of the Mykjunes tephra and Hekla 419 ka pumice compared to the Solheimar (Vedde Ash) ignimbrite pumices (Tomlinson et al. 2012) and other pumices.

\section{DISCUSSION}

The following labelling is used for stratigraphic units to avoid confusion with marine cold events: marine cold events as the $\mathrm{C} 25$ is defined here as M-C25. The Rangá interglacial Formation, frequently deformed by glacitectonism, thus seems to predate the Late Glacial and the retreat of the Weichselian ice sheet at the regional scale. Member R-E represents the last deglaciation complex, and member R-D represents the Weichselian. As the Weichselian ice sheet was cold based (Geirsdóttir et al. 2007; Van Vliet-Lanoë et al. 2005), glacial erosion and deposition were limited allowing the preservation of pre-Weichselian deposits. Most of the material for building the Rangá Formation is inherited from subglacial eruption(s) of the Hekla and Veiðivötn systems (Fig. 1). The present-day sandur displays mostly a re-shaped morphology of the Rangá Formation sedimentary prism (Fig. 2). The difficulty to discriminate the Rangá Formation from the Late Glacial - Holocene deglaciation deposits is raised from their facies similarities. However, consolidation by smectite clays (File S11), faulting, fracturing, and abundance of hyaloclastite sand are the field's keys to identify the Rangá Formation, which is located in an interglacial stratigraphic position that predates the Weichselian glaciation.

\section{Age of the Rangá Formation}

The Rangá interglacial Formation is older than the Vedde Ash (11.8 cal. Ka BP, Figs. 7D and 9) and thus the Younger Dryas morainic arcs (member R-D). The lower boundary of member $\mathrm{C}$ postdates porphyroid lava from Veiðivötn equating unit R-B1, cropping below unit R-C2 at Litlilækur (Fig. 4A; member R-B). The 40K-40Ar dating obtained (ISLN-84, Table 1) yielded $155 \pm 25 \mathrm{Ka}$ for glacially polished Veiðivötn lava. The MIS 6 age of this subaerial lava flow is probably subcontemporaneous of the Ófærugil event and the interstadial observed between 155 and $143 \mathrm{Ka}$ in Europe and Greenland (Seidenkrantz et al. 1996) forced by insolation (Adrielsson and Alexanderson 2005; Toucanne et al. 2009). The other arguments for our interpretation are derived from the stratigraphic and palaeoclimatic record (Figs. 10 and 12; see member R-C). The Rangá Formation records thus at least the last interglacial, classically bracketed between $132 \mathrm{Ka}$ and the marine cooling event M-C24 ca. 113 Ka BP (Drysdale et al. 2007; Govin et al. 2015). 
Van Vliet-Lanoë, B., Schneider, J.L., Guðrmundsson, Á., Guillou, H., Nomade, S., Chazot, G., Liorziou, C., Guégan, S., 2017. Eemian estuarine record forced by glacio-isostasy (S Iceland) link with Greenland and deep sea records. Can. J. Earth Sc. In press

doi.org/10.1139/cjes-2017-0126

\section{Chronological implications \\ Termination II}

The record of deglaciation in the Northern Atlantic seems to begin from $132 \mathrm{Ka}$ and is fully finished at $129 \mathrm{Ka}$ BP (Govin et al. 2015), as for the Greenland ice sheet deglaciation (NEEM ice core; Dahl-Jensen et al. 2013). In western and southern Iceland, Termination II seemed synchronous, although glacial advances and retreats were here triggered by high precipitations, in a position under the direct influence of the mild Irminger Current, as for the last deglaciation (Termination Ib, Jennings et al. 2000). In southeast Snæfellness, the Gerðuberg subaerial lava yielded $135 \pm 5 \mathrm{Ka} \mathrm{BP}$ (Table 1; File S31), attesting of an early deglaciation of this area and a full deglaciation at ca. $129 \mathrm{Ka}$ BP (Ljósufjöll, Table 1; Table S31) although the Prestahnukur seems still under the ice of the Langjökull at $132 \pm 19 \mathrm{Ka}$ (Clay et al. 2015). The $129 \mathrm{Ka}$ lava flow of the Ljósufjöll (ISLN-99, Table 1) predated immediately a similar formation as the Rangá Formation, close to the Eldborg volcano (Figs. 1A and 12), with a relative sea level close to $25 \mathrm{~m}$. In the core MD 99-2247 (Reykjanes ridge, Verpoorter 2005, sedimentary age model), the melting of the South East Icelandic ice caps is recorded from ca. 130 to 124 Ka BP. It should suggest a similar range for the onset of the Eemian in the southern embayment. If our age model is correct, this should suggest that the lateral moraine at Nærfurholt (120 m a.s.l.) and the residual basal till below the Rangá Formation at Svinagi (Fig. 2) are probably somewhat older than $129 \mathrm{Ka} \mathrm{BP,} \mathrm{marking} \mathrm{a}$ stillstand within the Saalian deglaciation. An age ranging ca. 129-127 Ka BP for the setting of the proglacial lacustrine units R-C1 and R-C2 is thus plausible. No evidence of ice front calving has been observed until now, a main difference with Terminations Ib and Ia (Geirsdóttir et al. 2000; Ingólfsson et al. 2009). The deglaciation during Termination II was extremely rapid, (Dalh-Jensen et al. 2013), much more than the Late Glacial twosteps deglaciation. It justifies here a very fast deglaciation (Fig. 11) under the direct influence of the mild Irminger Current and insolation. The sea level was close to the present-day level already at $128 \mathrm{Ka}$ BP (Medina-Elizalde 2013). It explains a very rapid flooding of the deglaciated surfaces and a lapping on old morainic arcs (e.g., Lambeck and Chappell 2001; Fig. 12).

\section{The optimum}

The major jökulhlaup deposit (subunit R-C3a), reworking Grim 1 tephra, is preserved above a relative sea level of70ma.s.l. on the eastern side of the embayment. In the north of the isle, a similar flood that records four successive slackwater deposits reworking Grimsvötn tephra also sign major jökulhlaup deposit (Fig. 11, base of the Syðra Normelsfjall Formation; File S21; Van Vliet-Lanoë et al. 2005). Both deposits suggest that the full deglaciation of the western Vatnajökull is early and extensive, but some relict ice persisted at Grimsvötn as also probably on the Langjökull, as for the Holocene (Björnsson 2009). It corresponds to the insolation maximum at $127 \mathrm{Ka} \mathrm{BP}$ (Govin et al. 2015) and thus the maximum of unloading of Vatnajökull. It means that the first marine highstand is slightly younger in age. During the Eemian, after the thermal optimum, pulsed marine cooling events were discovered in mid-Atlantic cores from 124 (M-C27a) to 117 Ka BP (M-C25) (Oppo et al. 1997; Fronval et al. 1998; Rasmussen et al. 2003). In NGRIP ice core, the cooling is progressive (Glacial Stadial GS 26, Fig. 12). The Grimsvötn volcano seems to be the most active volcano during the Holocene (Larsen et al. 1998), mostly erupting in a subglacial context (Óladóttir et al. 2011). Eruption frequency is rather constant in time (10 years), with higher activity cycles of 60-80 years (Óladóttir et al. 2011). It is thus difficult to attribute a specific eruption to each tephra, as they probably correspond to periods of high activity affecting quasisynchronously several volcanic centers.

Davies et al. (2014) suggested that tephra emission occurred in correlation with marine cooling events, especially M-C24 and M-C23, from the reinterpretation of MD99-2253 marine core, although eruptions should be more frequent with deglaciation events (Maclennan et al. 2002). In the Rangá Formation, located $150 \mathrm{~km}$ ahead to the south-west, decimeter to meter thick stratified tephra with lapilli

and reworked from the Grimsvötn volcano most probably correspond to slack water deposits from deglaciation jökulhlaups (Grim 1, 5, and 6) issued from the caldera, and potentially also from successive eruptions. The thick Grim 1 tephra is in a similar position as for the Holocene Saksunarvatn tephra (at least 5-6 eruptions, Johannsdottir 2007) but in a former interglacial older than the Vedde Ash (MIS 5). Grim 1 in the Rangá Formation yields a bulk chemistry (Fig. 8, File S21; lapilli: $100 \%$ glass) very close to the 5e low Bas-IV of 
Van Vliet-Lanoë, B., Schneider, J.L., Guðrmundsson, Á., Guillou, H., Nomade, S., Chazot, G., Liorziou, C., Guégan, S., 2017. Eemian estuarine record forced by glacio-isostasy (S Iceland) link with Greenland and deep sea records. Can. J. Earth Sc. In press

doi.org/10.1139/cjes-2017-0126

marines cores (Davies et al. 2014). The 5e low Bas-IV tephra yield an age of ca. $127 \mathrm{Ka}$ BP (marine age model, Davies et al. 2014).

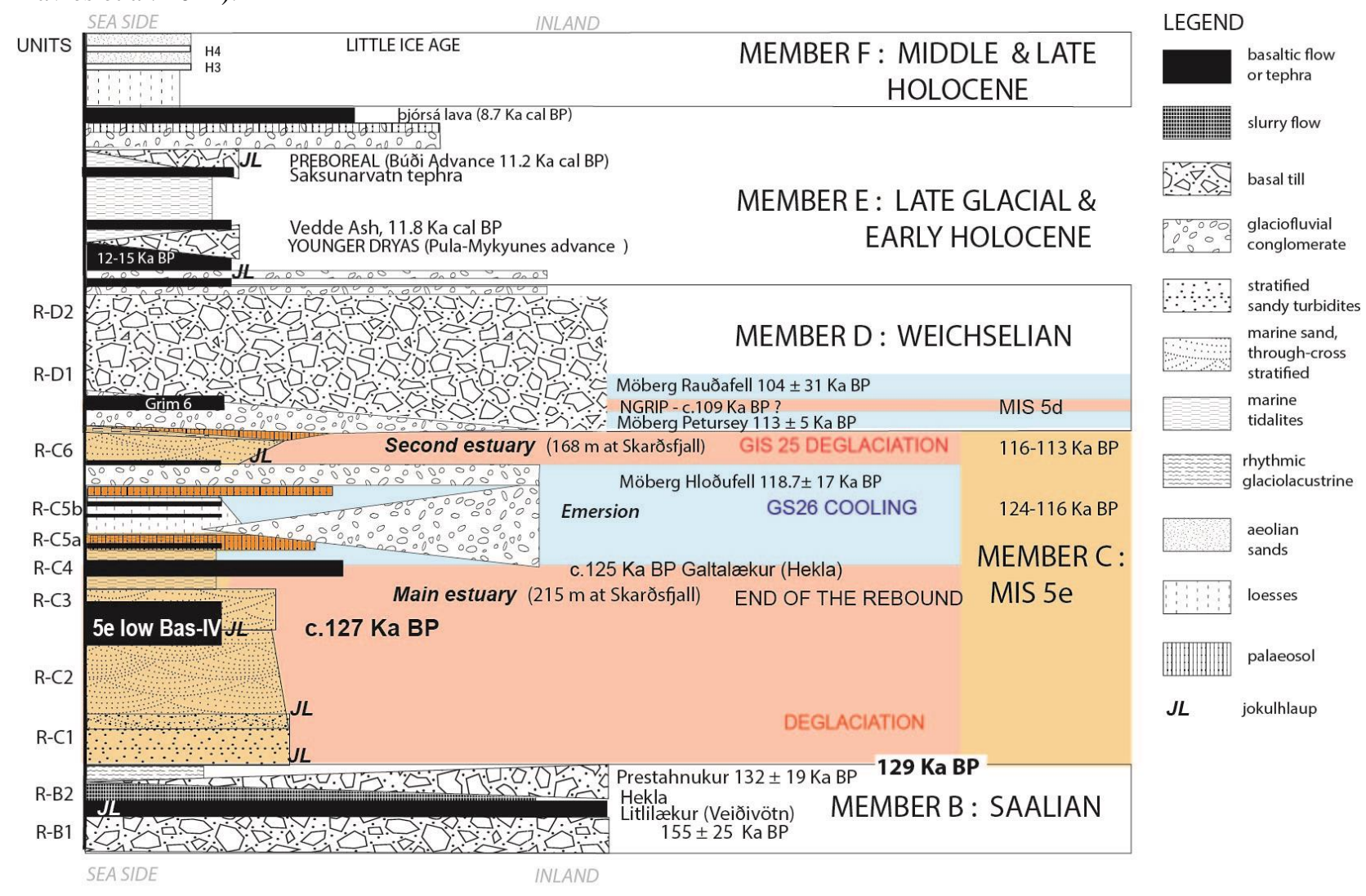

Fig. 10. Composite stratigraphic log of the Rangá Formation. JL, jökulhlaup deposit.

The phreatomagmatic character of the 5e low Bas-IV and Grim 1 jökulhlaup deposit both suggest a persisting glacier on Grimsvötn at the MIS 5e thermal optimum (127 Ka BP; synthesis in Govin et al.

2015). Both tephra are apparently synchron. The most recent Grimsvötn tephra from Hellar cave crops close to the top of the Rangá Formation (late R-C6). It is younger than the second warming of the Eemian, GI 25 $(116-113 \mathrm{ka})$. Its reworking in the form of jökulhlaup slackwater deposit suggests the end of a more recent warming, possibly the MIS 5c interstadial, ca. $110 \mathrm{Ka}$ BP. A single Grimvötn tephra is record at that time in NGRIP ice core (ca. 109 Ka BP; MIS 5c; ice-flow age model; Davies et al. 2014). Chronology for the other Grimvötn tephra is extrapolated from an age regression model between the base of R-C4 (ca. $127 \mathrm{ka}$ ) and the top of R-C5 (ca. $116 \mathrm{ka})$, assuming a more or less regular speed of sedimentation $(150 \mathrm{~cm} / 10 \mathrm{ka}$, Heiðarbrekka section), as well for the tidal mud as for the loess (Fig. 8). These observations are very similar to our former observations bracketing the last interglacial formation in the north of Iceland (Fig. 12). At Hálslón (north of Vatnajökull), this formation is much older than the Askja S/10 ka tephra (11.4 cal. Ka BP; Davies et al. 2003; Guégan 2010; Lind and Wastegård 2011) and is bracketed between 150 and 103 Ka BP (Van Vliet-Lanoë et al. 2010). In the north, aerial lava flow yields ca. 81 Ka near Morðurdalur (Guillou et al. 2010, Table 1), resting of an interglacial formation, the Syðra Normelsfjall Formation (Van Vliet-Lanoë et al. 2005; Fig. 12; Table 1): the Grimsvötn tephra at the base of this formation is very similar to Grim 1 complex tephra (File S21).The Rangá Formation records thus the last interglacial, classically bracketed between $132 \mathrm{Ka}$ and the marine cooling event M-C24, ca. $113 \mathrm{Ka}$ BP to the transition between MIS 5D and MIS 5C (110-109 ka). 
Van Vliet-Lanoë, B., Schneider, J.L., Guðrmundsson, Á., Guillou, H., Nomade, S., Chazot, G., Liorziou, C., Guégan, S., 2017. Eemian estuarine record forced by glacio-isostasy (S Iceland) link with Greenland and deep sea records. Can. J. Earth Sc. In press

doi.org/10.1139/cjes-2017-0126

After the thermal optimum, pulsed marine cooling events are recorded (synthesis in Rasmussen et al. 2003) and in NGRIP ice core, the cooling is progressive (GS 26, Fig. 12). We may expect a similar answer from Icelandic ice sheets. The complex cooling of GS 26 or of M-C25 and M-C26 are followed by an important warming (Glacial Interstadial GI 25, 116-113 Ka BP, Fronval et al. 1998; Rasmussen et al. 2003) before the onset of MIS 5d glacial (M-C24-C23 cold events; Oppo et al. 1997). Glaciers form when precipitations are still high (Broecker and Denton 1990) and the dating of subglacial volcanoes may help to reconstruct their early development. To the west of the central plain, the Hlöðufell móberg yields $118.7 \pm 17 \mathrm{Ka}$ BP in age (Fig. 1A,south of the Langjökull; ISLN-73, Table 1). It attests of an early glaciation and cooling apparently within the Eemian. TheLangjökull ice cap by its western exposition is very sensitive to precipitation related with the vicinity of the Irminger Current. The southern and eastern Greenland ice sheet (Fronval et al. 1998; Irvali et al. 2016) had pulsed advances at 119 and $117 \mathrm{Ka}$. A partial deglaciation occurred close to $116 \mathrm{Ka}$ inland, allowing the setting of unit R-C6 in the Rangá Formation and a full retreat of the eastern Vatnajökull at Halslòn (Fig. 1A; Van VlietLanoë et al. 2010), both corresponding to the GI 25. It means a delay of ca. 9 Ka between the two climatic optima and potential marine transgressions. The $113 \pm 25 \mathrm{Ka} \mathrm{BP}$ age of Petursey móberg, south of Mýrdalsjökull (Fig. 1A, $260 \mathrm{~m}$ a.s.l.; ISLN-81, Table 1) also fits the regional entrance in glaciation and the high precipitation on this ice sheet. During the same period, cooling glaciers mostly thicken, especially in altitude. The age of the Rauðafell, $104 \pm 31$ Ka BP (ISLN-71, Table 1), southwest of the Hlöðufell móberg attests with the Hellar cave tephra (Grim 6, potentially $109 \mathrm{Ka} \mathrm{BP}$ ) that glaciers did not yet occupy the central embayment before ca. $109 \mathrm{Ka}$ BP but were well expanded on the plateau. It seems even later for the north of Iceland $(<81 \pm 9 \mathrm{Ka}$ at Skarðsengi, Table 1; Guillou et al. 2010). Rebound, glaciation, and relative sea level The speed and amount of postglacial rebound is controlled by the viscosity of the mantle and the regional ice loading history (e.g., Cuffey and Paterson 2010). These factors have been analyzed in detail by Biessy et al. (2008) for southern Iceland. Fast rebound rates were estimated for the Skagi peninsula in northern Iceland $(10 \mathrm{~cm} /$ year; Rundgren et al. 1997) and for southwestern Iceland $(6.9 \mathrm{~cm} /$ year.; Ingólfsson et al. 1995). For the last deglaciation in the southern embayment, Biessy et al. (2008) estimated an uplift rate of $8.2-10.5 \mathrm{~cm} /$ year. The duration is estimated as 1430 years from Termination Ib. For the onset of the last deglaciation, the ice thickness is estimated to reach 400-300 m south of Langjökull (Licciardi et al. 2007). This should suppose that at Termination II, the ice volume was similar to Termination $\mathrm{Ib}$, due to a comparable rate of glacio-isostatic rebound. The observed glacio-isostatic rebound implies $300 \mathrm{~m}$ of residual ice around the Búrfell at the onset of the Eemian (Termination II, before MFS1) and implies a possible thickness of $200 \mathrm{~m}$ of ice before MFS2 upstream of the Búrfellrhaun with thickened plateau ice sheets (during unit R-C5 deposition, Fig. 4A). During the Zeifen oscillation (MIS 6b; 155$150 \mathrm{Ka}$ BP events, unit R-B2), the ice thickness at the foot of the Hekla volcano (Norðubjallar ridge, 500ma.s.l., down to Ófærugill,200 m a.s.l.) was similar to the early Eemian situation $(200-300 \mathrm{~m})$. From the lowest outcrops of unit R-B3 (Fig. 1B), we may assume that the relative sea level was close to the present-day relative sea level just before 129 Ka BP (Fig. 12). At Snæfellsness (Fig. 1A), the Ljösufjöll subaerial lava, glacially abraded at the foot of the Holocene Eldborg volcano, suggests a relative sea level close to $+25 \mathrm{~m}$ a.s.l., just after $129 \mathrm{Ka}$ (red point on Fig. 12). Unit R-C1 is lacustrine and the relative sea level is largely below 80 ma.s.l. at that time. At ca. $127 \mathrm{Ka} \mathrm{BP}$, the setting of Grim 1 tephra above $60 \mathrm{~m}$ a.s.l. suggests a relative sea level close to this altitude. The presence at $215 \mathrm{~m}$ a.s.l. of tidal deposits on the Skarðsfjall indicates a high relative sea level and suggests a rapid rise to MFS1 during the deglaciation of the pre-existing ice sheet. The maximal glacioisostatic rebound should thus represent a duration of 1120-1440 years for the main rebound, as for Termination Ib.The formation of the pro-glacial lake fed by jökulhlaups, in which unit R-C1 prograded (recurrent turbidites induced by pulsed floods), attests of an active glacial rebound, with a forbulge propagating to the inland (Fig. 4A), leading to a landward penetration of the estuary. 
Van Vliet-Lanoë, B., Schneider, J.L., Guðrmundsson, Á., Guillou, H., Nomade, S., Chazot, G., Liorziou, C., Guégan, S., 2017. Eemian estuarine record forced by glacio-isostasy (S Iceland) link with Greenland and deep sea records. Can. J. Earth Sc. In press

doi.org/10.1139/cjes-2017-0126

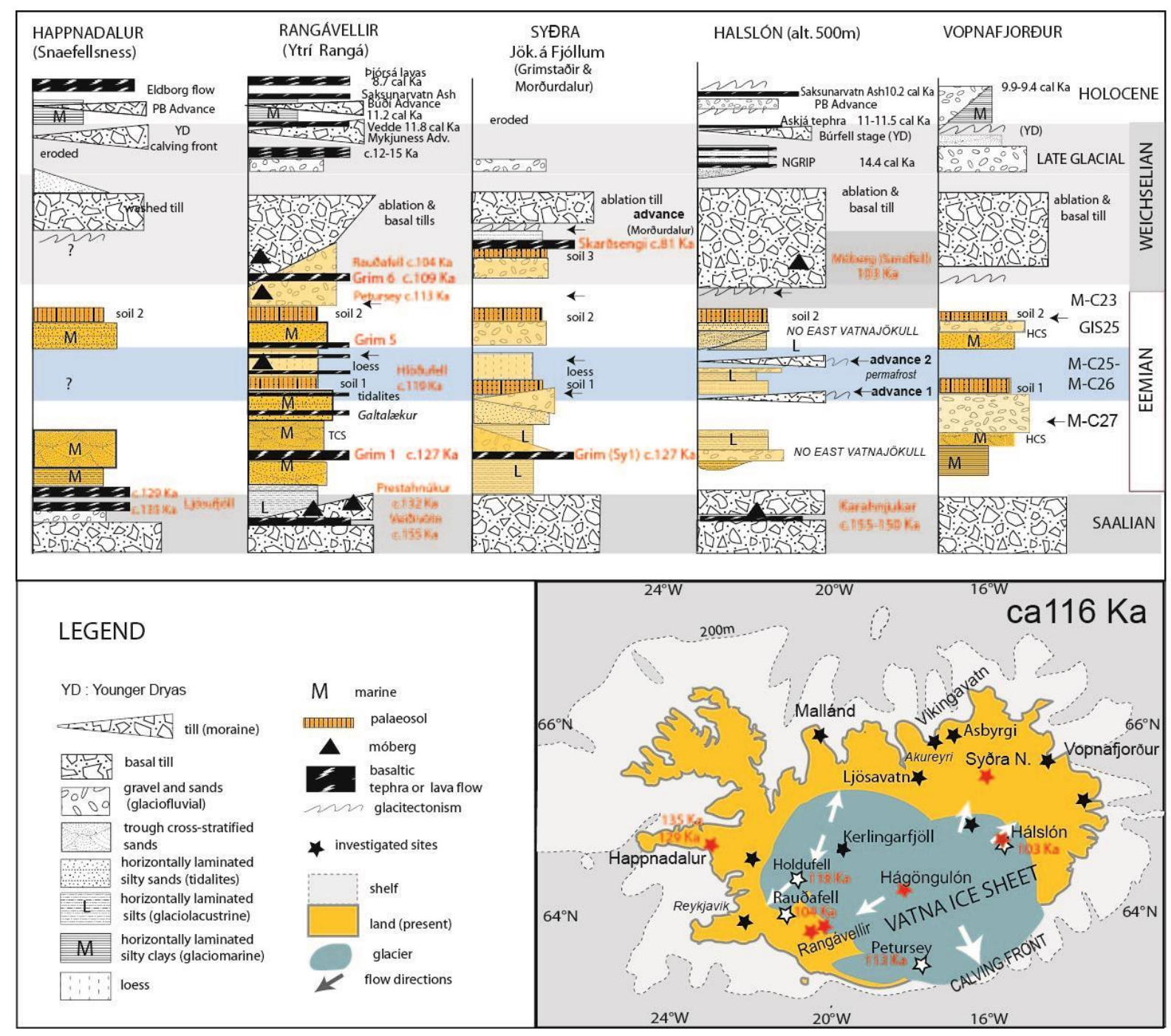

Fig. 11. Record of the intra-Eemian cooling in Iceland (data from Van Vliet-Lanoë et al. 2005, 2007, 2010), with a reconstitution of the potential glacial extent at ca. $116 \mathrm{Ka}$. Black arrows: glaciofluvial progradation. Map: red stars: main sites; white stars: early Weichselian extent. Dating available in Table 1.

Most of the glacial rebound seems achieved regionally close to 126-125 Ka BP with ending unit R-C2 and the first MFS on the Skarðsfjall, despite the ongoing global sea level rise (Medina-Elizalde 2013). Units R-C3 and R-C4 already correspond, respectively, to a stillstand by ca. $1 \mathrm{Ka}$ long and to the onset of a forced regression as proved by a deltaic progradation, associated with a diachronic emersion and a cooling (unit R-C5). With the end of the rebound, the river slope became steeper and the vertical erosion more efficient with higher sedimentary discharge (Fig. 4B). Unit R-C5 is followed by a rapid return to temporary marine conditions (unit R-C6). It implies a late but rapid glacio-isostatic rebound resulting from a deglaciation of the nearby ice sheets driven by GI 25 (Fig. 12). The delay of ca. 9 Ka between the two climatic optima with potential marine transgressions is consolidated by the tephrostratigraphy. Consequently, MFS2 (168ma.s.l.,Figs. 11 and 12) cannot be considered as a secondary late maximum. of the regional transgression.

The renewed glacio-isostatic deformation of the basement for units R-C5 and R-C6 should represent a duration of 1600 years for the glacier building and a similar one for the second rebound..Glacially forced transgressions and regressions related with intra-Eemian cooling events Most of the deposition of the Rangá Formation (Fig. 4B) took place prior to unit R-C3 emplacement. Units R-C2 to R-C4 traced a forced delta progradation and emersion, in a context of enhanced storminess and cooling. Storms could enhance temporarily the tidal range 
Van Vliet-Lanoë, B., Schneider, J.L., Guðrmundsson, Á., Guillou, H., Nomade, S., Chazot, G., Liorziou, C., Guégan, S., 2017. Eemian estuarine record forced by glacio-isostasy (S Iceland) link with Greenland and deep sea records. Can. J. Earth Sc. In press

doi.org/10.1139/cjes-2017-0126

allowing decametric channel incision (Morton and Sallenger 2003). It fits the cooling M-C27a (127-123 Ka BP) ending with a developing mudflat and the setting of Grim 3 tephra (ca. $122 \mathrm{Ka} \mathrm{BP}$ ). This justifies the model of Kaspar et al. (2007), which describes enhanced storminess on the Northern Atlantic during the period following the thermal optimum of the MIS 5e (127 Ka BP). Afterwards, the successive cooling events (M-C26 and M-C25, NGRIP GS 26, Fig. 12) limited recurrently the vegetation cover inland and allowed loess deposition (unit R-C5). It was lately perturbed by a cumulative, but temporary, glacial twined advances in central Iceland (Halslón Lake, Fig. 11; Van Vliet-Lanoë et al. 2010). The altitude of the relative sea level lowstand is not known in the Rangá Formation but probably close to the main Eemian HS (Fig. 12). This compound glacial pulse resulted by melting (NGRIP GI 25 deglaciation) in the building of a lower secondary sedimentary prism, unit R-C6 (Fig. 4), also documented as glaciofluvial at Halslón Lake (Fig. 11).

\section{Time Ka BP}

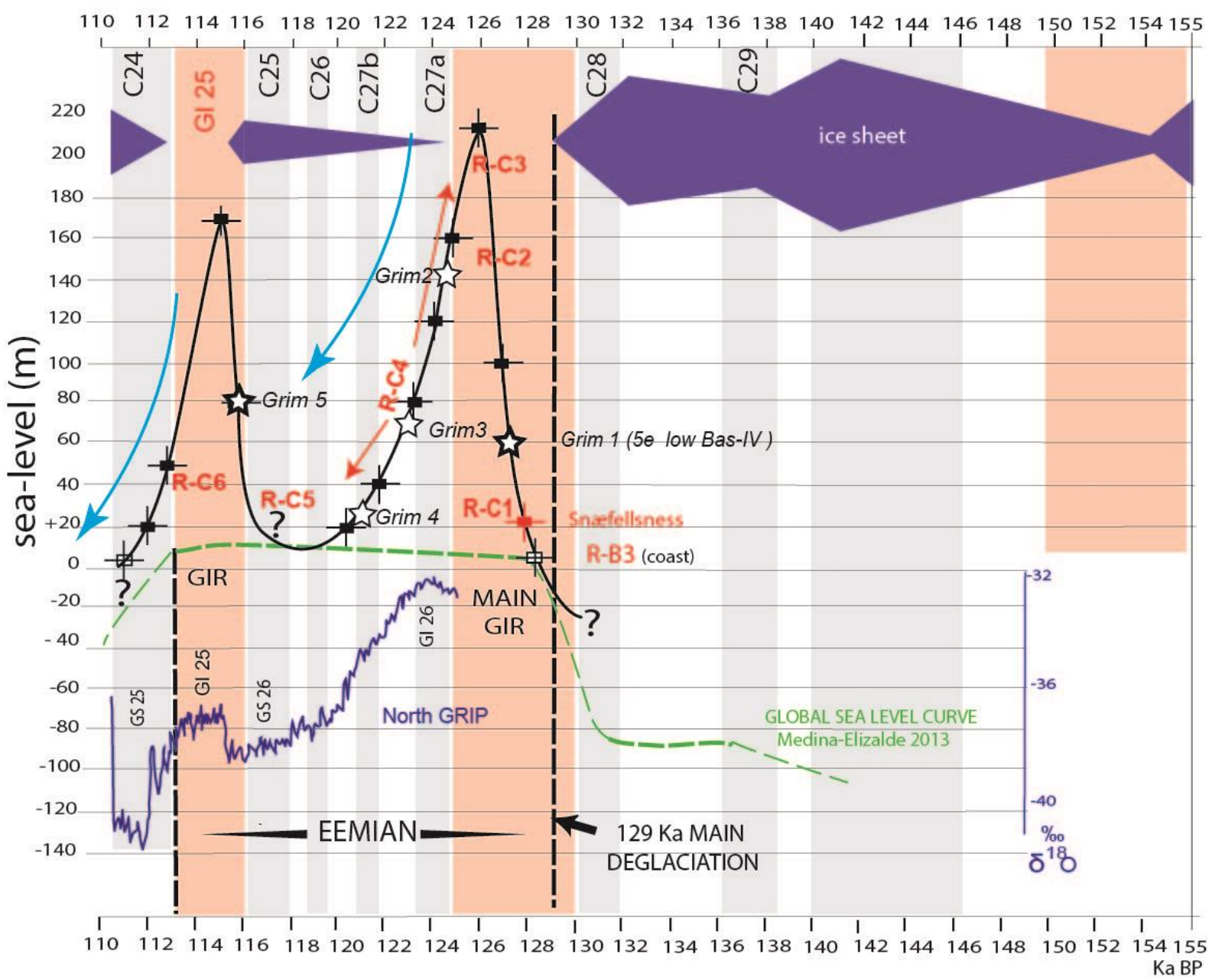

Fig. 12. Apparent eustatic curve for the setting of the Rangá Formation. Error bar on the filled points: $\pm 5 \mathrm{~m}$; the empty points are for submarine sites around Iceland, submarines terraces (Biessy et al. 2008). This curve is compared to the raw Eemian curve on corals (Medina-Elizalde 2013) and North Grip ice core isotopic record (Andersen et al. 2004) with warming (GI) and cooling (GS) events. C24-C29: marine cold events (Frontval and

Jansen 1997; Oppo et al. 1997). Time tuning extracted from Drysdale et al. (2007). GIR, glacio-isotatic rebound. Blue arrows: forced regressions.

Unit R-C6 attests here of a brief marine re-flooding, in association with recurrent jökulhlaups, close to the top of the Rangá Formation (Figs. 3D and 5) in association with a brief and apparent rise of the relative sea level on the Skarðsfjall and on Merkurhaun to $168 \mathrm{~m}$ a.s.l. In northern Iceland, far from the glacial centers, these highstands 
Van Vliet-Lanoë, B., Schneider, J.L., Guðxmundsson, Á., Guillou, H., Nomade, S., Chazot, G., Liorziou, C., Guégan, S., 2017. Eemian estuarine record forced by glacio-isostasy (S Iceland) link with Greenland and deep sea records. Can. J. Earth Sc. In press

doi.org/10.1139/cjes-2017-0126

appear separated by a brief regression only, particularly in the estuary of Vopnafjörður and at Malland (Skagí peninsula, Fig. 11).

\section{Synthesis}

Glaciers usually rapidly develop at the onset of glaciations, when precipitations are still high. After a rapid deglaciation, MFS1 is reached ca. $126 \mathrm{Ka}$ BP in the Rangávellir. Progressive GS 26 cooling in Greenland, but pulsed in marine cores (M-C26 and M-C25), lead to limited glacial advances along eastern Greenland. In Iceland, it implied a reconstruction in altitude of most south and western ice sheets. The sea level being close to that of presentday (Fig. 12) enabled significant precipitation thanks to the pulsed mild Irminger Current. This first period of reconstruction of the ice sheets has a total duration of ca. $5 \mathrm{Ka}$, compatible with the calculated laps for glacio-isostatic unloading for unit R-C6 (ca. $1.6 \mathrm{Ka}$ ). Twinned glacial pulses were already observed at the northeastern part of Vatnajökull under control of M-C26 and M-C25 cooling, also expanding the Langjökull and the Vatnajökull in altitude. The still unglaciated southern embayment only recorded a cooling with a marine regression and loess deposition (units R-C4 and R-C5). With the Greenland GI 25 interstadial (116-113 Ka BP), the last mild event of MIS 5e (Fig. 12), a temporary restoral of the thermohaline circulation allowed a return to interglacial conditions in the East Atlantic (Rasmussen et al. 2003) and along the Reykjanes Ridge (Verpoorter 2005). This configuration fits the setting for unit R-C6 and MFS2 in the Rangá Formation. This warming was followed by the regional main entrance in glaciation at least from $113 \mathrm{Ka}$ at the foot of the Mýrdalsjökull in the south, but it was delayed to $103 \mathrm{Ka}$ in the colder and dryer area north of Vatnajökull (Van Vliet-Lanoë et al. 2010).

\section{CONCLUSION}

In central southern Iceland, the Rangá interglacial Formation clearly predates the Weichselian and the last deglaciation, but it is younger than $155 \mathrm{Ka} \mathrm{BP}$. It records the period covering MIS 5e, the Eemian sensu-stricto, and MIS 5d, representing a time span of ca. 128-127 to $109 \mathrm{Ka} \mathrm{BP}$. It records a very rapid deglaciation (Termination II), the Eemian optimum with some relict ice, the intra-Eemian cooling GS 26, and the late warming of GI 25. It preserves two successive and distinct transgressive system tracks (tidal lagoon infill) separated by ca. 9 Ka, MFS1 and MFS2, and an emersion (Figs. 10 and 12). These two superposed MFS result from glacially forced regression controlled by the vicinity of the main Icelandic ice sheets. The Grimsvötn and Hekla volcanoes seem highly active. As for the Holocene, the frequency of jökulhlaups increased during Eemian deglaciation events. The spectacular preservation of this interglacial prism is related to the major topographical shaping by the Saalian ice sheet, the rapid deglaciation of Termination II, and the cold-based character of the Weichselian glaciation that prevented subsequent erosion. The average preserved thickness of the Rangá Formation reached probably $30 \mathrm{~m}$, although the Termination I prism is discretely preserved in incised valleys and displays a thickness of only $15 \mathrm{~m}$ (on average). This Eemian estuarine infill records the distal signature of a complex glacial advance during the interglacial, already well observed and bracketed in time in northern and central Iceland. It is the first terrestrial sequence that allows, thanks to tephrostratigraphy, the linking of climate events recognized in marine and ice cores to the ice sheet dynamic, within a key position

in the central Northern Atlantic. To the south, in eastern Canada, the only comparable record should be the second unit of the Don Formation ( $43^{\circ} \mathrm{N}$; Occhietti et al. 2016) also including two limited coolings, covering MIS 5e and the onset of MIS5d.

\section{ACKNOWLEDGEMENTS}

This study was funded by the IPEV-French Polar Research Program number 316 (ICPROCI I, II, and III) for field work in Iceland. We also thank Audrey Wayolle and Guillaume Gosselin for their assistance during field work in 2006 and 2008. We also greatly thank one reviewer for his very constructive comments and his understanding of the importance of the Rangá Formation. 
Van Vliet-Lanoë, B., Schneider, J.L., Guðrmundsson, Á., Guillou, H., Nomade, S., Chazot, G., Liorziou, C., Guégan, S., 2017. Eemian estuarine record forced by glacio-isostasy (S Iceland) link with Greenland and deep sea records. Can. J. Earth Sc. In press

doi.org/10.1139/cjes-2017-0126

\section{REFERENCES}

Adrielsson, L., Alexanderson, H., 2005. Interactions between the Greenland Ice Sheet and the Liverpool Land coastal ice cap during the last two glaciation cycles. J.Quatern.Sci., 20, 3: 269-283.

Ahronson, K., 2015. Into the Ocean. Vikings, Irish, and Environmental Change in Iceland and the North. University of Toronto Press. Toronto. 245 pp.

Allen, J.R.L, 1982. Mud drapes in sand-wave deposits: a physical model with application to the Folkestone Beds (Early Cretaceous. Southeast England). Phil Trans.R.Soc. London A306: 291-345.

Andrews, J.T., Geirsdóttir, Á., Principato S., Kristjánsdóttir, G.B., Helgadóttir, G., Hardardóttir, J., Grönvold, K., Sveinbjörnsdóttir, Á., Drexler, J. 2002. Distribution. age and geochemistry of the Saksunarvatn $10,18 \mathrm{cal} \mathrm{Ka}$ ) ash in marine, lake, and terrestrial sediments, NW Iceland. J.Quatern.Sci. 17, 8: 731-74.

Arnalds, O., Thorarinsdóttir, E,F., Metusalemsson, S., Jonsson, A., Gretarsson, E., Arnorsson, A., 1997. Soil Erosion in Iceland. Reykjavik: Soil Conservation Service and Agricultural Research Institute. English translation 2000, $157 \mathrm{pp}$.

Biessy, G., Dauteuil, O., Van-Vliet Lanoë, B., Wayolle, A., 2008. Fast and partioned post-glacial rebound of south-western Iceland. Tectonics 27: TC3002, doi:10.1029/2007TC002177.

Björnsson,. H., 2009. Jöklar á Íslandi. Bókaútgáfan Opna, Reykjavík. 479 p. English translation 2017 The Glaciers of Iceland, Atlantis Adv.Quatern.Sci. 2, 613 p., Atlantis Press, Springer.

Björnsson, H., 2002. Subglacial lakes and jökulhlaups in Iceland. Global Planet. Change, 35:255-271

Brady, N.C., 1990. The Nature and Properties of Soils, 10th ed. New York: Macmillan Publ. Comp., 103110 pp.

Broecker, W.S., Denton, G.H., 1990. The role of ocean-atmosphere reorganisation in glacial cycles. Quatern.Sci.Rev., 9: 305-341.

Carey, S., Maria, A., Sigurdsson, H., 2000. Use of fractal analysis for discrimination of particles from primary and reworked jökulhlaup deposits in SE Iceland. J.Volcanol. Geotherm.Res., 104:65-80.

Charbit, S., Guillou, H., Turpin, L., 1998. Cross calibration of K-Ar standard minerals using an unspiked Ar measurement technique. Chem.Geol., 150: 147-159.

Clay, P.L., Busemann, H.,Sherlock, S.C., Barry, T.L., Kelley, SP, McGarvie, D.W. (2015). 40Ar/39Ar ages and residual volatile contents in degassed subaerial and subglacial glassy volcanic rocks from Iceland. Chem.Geol. 403: 99-110.

Cuffey, K.M., Paterson, W.S., 2010. The Physics of Glaciers, 4th Edition Elsevier, 704 pp

Dahl-Jensen, D. and NEEM community members, 2013. Eemian interglacial reconstructed from a Greenland folded ice core. Nature, 493: 489-49.

Davies, S.M., Abbott, P.M., Meara, R.H., Pearce, N.J.G., Austin, W.E.N., Chapman, M.R.,. Svensson, A., Bigler, M., Rasmussen, S.O., Farmer, E.J., 2014. A North Atlantic tephrostratigraphical framework for 130-60 ka: new tephra discoveries, marine-based correlations, and future challenges. Quatern.Sci.Rev.,, 106: $101-121$.

Davies, S.M., Wastegård, S., Wohlfarth, S., 2003. Extending the limits of the Borrobol tephra to Scandinavia and detection of new Early Holocene tephras. Quatern.Res., 59: 345-352.

Drysdale, R.N., Zanchetta, G., Hellstrom, J.C., Fallick, A.E., McDonald, J., Cartwright, I., 2007. Stalagmite evidence for the precise timing of North Atlantic cold events during the early last glacial. Geology, 35: $77-80$.

Dumas, S., Arnott, R.W.C., 2006. Origin of hummocky and swaley cross-stratification. The controlling influence of unidirectional current strength and aggradation rate. Geology, 34,12: 1073-1076.

Einarsson, T., 1994. Geology of Iceland. Rock and landscape. Mal og menning. Reykjavík 294 pp.

Einarsson, P. and Eiríksson J. 1982.Earthquake fractures in the districts Land and Rangárvellir in the South Iceland Seismic Zone. Jökull, 32, 113-120, .

Eyles, N., Clark, B.M., Clague, J.J., 1987. Coarse-grained sediment gravity flow facies in a large supraglacial lake. Sedimentology, 34: 193-216.

Flude, S., Burgess, R., McGarvie, D.W., 2008 . Silicic volcanism at Ljósufjöll. Iceland: insights into evolution and eruptive history from Ar-Ar dating. J.Volcanol. Geotherm.Res., 169: 154-175. 
Van Vliet-Lanoë, B., Schneider, J.L., Guðmundsson, Á., Guillou, H., Nomade, S., Chazot, G., Liorziou, C., Guégan, S., 2017. Eemian estuarine record forced by glacio-isostasy (S Iceland) link with Greenland and deep sea records. Can. J. Earth Sc. In press

doi.org/10.1139/cjes-2017-0126

Frontval, T., Jansen, E., Halflidi, H., Sejrup, H.P., 1998. Variability in surface and deep water conditions in the Nordic seas during the last interglacial period. Quatern.Sci.Rev.,, 17: 963-985.

Fronval, T., Jansen, E., 1997 . Eemian and early Weichselian (140-60 ka) paleoceanography and paleoclimate in the Nordic seas with comparisons to Holocene conditions. Paleoceanography, 12: 443-462.

Geirsdóttir, Á., Harðardóttir, J., Eiríksson, J., 1997. Depositional history of the Younger Dryas ? -Preboreal sediments. South Central Iceland. Arctic Alpine Res. 29: 13-23.

Geirsdóttir, Á., Hardardóttir, J., Sveinbjörnsdóttir, Á.E, 2000. Glacial extent and catastrophic meltwater events during the deglaciation of Southern Iceland. Quatern.Sci.Rev.,, 19: 1749-1761.

Govin, A., Capron, E., Tzedakis, P.C., Verheyden, S., Ghaleb, B., Hillaire-Marcel, C., St-Onge, G., et al., 2015. Sequence of events from the onset to the demise of the Last Interglacial: Sequence of events from the onset to the demise of the Last Interglacial. Quatern. Sci. Rev., $129: 1-36$.

Guégan, S., 2010 . Géochimie et stratigraphie des Vedde Ash en Islande. Master Thesis, Master SML, Brest University, $52 \mathrm{pp}$.

Guillou, H., Van Vliet-Lanoë, B., Guðmundsson, A., Nomade, S. 2010. Climate-related Quaternary volcanic activity in Iceland? Insights from new unspiked K-Ar ages. Quatern.Geochron., 5, 1: 10-19.

Haflidason, H., Eiríksson, J., van Kreveld, S. 2000. The tephrochronology of Iceland and the North Atlantic region during the Middle and Late Quaternary: a review. J. Quat.Sci. 15: 3-22.

Halldorsson, S.A., Oskarsson, N., Gronvold K., Sigurdsson, G., Sverrisdóttir, G. Steinthorsson, S., 2008. Isotopic-heterogeneity of the Thjorsa lava - implications for mantle sources and crustal processes within the Eastern Rift Zone. Iceland. Chem. Geol., 255, 1-3: 305-316.

Hannesdóttir, H., Geirsdóttir, Á., Miller, G.H., Manley, W., 2009. Sediment deposition in lake Hestvatn, South Iceland, during the last deglaciation and the Holocene. Jökull, 59: 67-88.

Hansen, L.A., Jensen, J.B., Terkelsen, M., 1997. Pleistocene sedimentary record of the Falsterselv area, Jameson Land, East Greenland. Geol.Greenland Surv.Bull., 176:84-88.

Hjartarson, A., Ingólfsson, O., 1988. Preboreal glaciation of Southern Iceland. Jökull 38: 1-13.

Hütt, G., Punning, J.-M., Mangerud, J., 1983. Thermoluminescence dating of the Eemian-Early Weichselian sequence at Fjøsanger. western Norway. Boreas, 12: 227-231.

Ingólfsson, Ó., Norðdahl, H., Schomacker, A., 2009. Deglaciation and Holocene Glacial history of Iceland. In Schomacker, A., Krüger, J. \& Kjær, K. (eds.) The Myrdalsjokull ice cap, Iceland. Elsevier. D.Q.S. 13: 51-68.

Ingólfsson, Ó., Norðdahl H., 2001. High relative sea-level during the Bølling Interstadial in western Iceland: a reflection of ice sheet collapse and extremely rapid glacial unloading. Arct.Antarct.Alp.Res., 33: 231243.

Ingólfsson, Ó., Norðdahl, H., Haflidason, H., 1995. Rapid isostatic rebound in southwestern Iceland at the end of the last glaciation. Boreas, 24: 245-259.

Irvali. N., Ninneman U.S., Helga Kleiven H.F., Galaasen E. V., Morley A., Rosenthal Y., 2016. Evidence for regional cooling, frontal advances, and East Greenland Ice Sheet changes during the demise of the last interglacial. Quaternary Science Reviews 150 184-199. doi.org/10.1016/j.quascirev.2016.08.029

Jackson, M.G., Oskarsson, N., Trønnes, R.G., McManus, J.F., Oppo, D.W., Grönvold K., Hart, S.R., Sachs, J.P., 2005 . Holocene loess deposition in Iceland: Evidence for millennial scale atmosphere-ocean coupling in the North Atlantic. Geology, 33, 6: 509-512.

Jennings, A., Syvitski, J., Gerson, L., Grönvold, K., Geirsdóttir, Á., Hardardóttir, J., Andrews, J., Hagen, S., 2000. Chronology and paleoenvironments during the Late Weichselian deglaciation of the Southwest Iceland Shelf. Boreas, 29: 167-183.

Johannsdottir, G.E., 2007. Mid-Holocene to late glacial tephrochronology in west Iceland as revealed in three lacustrine environments. MS thesis, Univ Iceland, Reykjavík.

Johnson, H., 1977 . Shallow marine sand bar sequences: an example from the late Precambrian of North Norway. Sedimentology, 24 (2): 245-270.

Kaldal, I., Vilmunðarsdóttir, E.G., 1986. Map of the superficial deposits Búrfell-Langalda. Nr. 3540J. National Energy Authority and National Power Company. Reykjavik, Iceland. 
Van Vliet-Lanoë, B., Schneider, J.L., Guðmundsson, Á., Guillou, H., Nomade, S., Chazot, G., Liorziou, C., Guégan, S., 2017. Eemian estuarine record forced by glacio-isostasy (S Iceland) link with Greenland and deep sea records. Can. J. Earth Sc. In press

doi.org/10.1139/cjes-2017-0126

Kaspar, F., Spangehl, T., Cubasch, U., 2007 . Northern hemisphere winter storm tracks of the Eemian interglacial and the last glacial inception. Clim. Past., 3: 181-192.

Kristjánsson, L., Duncan, R., Gudmunðsson, Á., 1998. Stratigraphy, palaeomagnetism and age of volcanics in the upper regions of pjórsárdalur valley, central southern Iceland. Boreas 27: 1-13.

Lambeck K., Chappell J. 2001Sea level change through the last glacial cycle.Science. 2001 Apr 27;292(5517):679-86.

Lane, C.S., Blockley, S.P.E., Mangerud, J., Smith, V.C., Lohne, Ø.S., Tomlinson, E.L., Matthews, I.P., Lotter, A.F., 2012 . Was the 12,1 Ka Icelandic Vedde Ash one of a kind? Quatern.Sci.Rev., 33: 87-99.

Larsen, G., Guðmundsson, M.T., Björnsson, H. (1998). Eight centuries of periodic volcanism at the center of the Iceland hot spot revealed by glacier tephrastratigraphy. Geology, 26(10): 943-946.

Licciardi, J.M., Kurz, M.D., Curtice, J.M., 2007. Glacial and volcanic history of Icelandic table mountains from cosmogenic 3He exposure ages. Quatern.Sci.Rev.,, 26: 1529-1546.

Lind, E.M., Wastegård, S., 2011. Tephra horizons contemporary with short early Holocene climate fluctuations: new results from the Faroe Islands. Quatern.Inter. , 246: 157-167.

Maizels, J.K., 1997. Jökulhlaup deposits in proglacial areas. Quatern.Sci.Rev., 16: 793-819.

Mangerud, J., Sønstegaard, E., Sejrup, H.P., Haldorsen, S., 1981. A continuous Eemian-Early Weichselian sequence containing pollen and marine fossils at Fjøsanger, western Norway. Boreas, 10: 137-208.

Maclennan, J., Jull, M., McKenzie, D., Slater, L., Grönvold, K., 2002. The link between volcanism and deglaciation in Iceland. Geochem.Geophys.Geosyst. 3,11: 1062, doi:10.1029/2001GC000282.

McKee, E.D., 1957. Flume experiments on the production of stratification and cross-stratification. J. Sed. Petrol., 27, 2: 129-134.

Medina-Elizalde, M., 2013. A global compilation of coral sea-level benchmarks: Implications and new and challenges. Earth Planet.Sci.Lett. 362: 310-318.

Möller, P., Fedorov, G., Pavlov, M., Seidenkrantz, M.S., Sparrenbom, C., 2008 . Glacial and palaeoenvironmental history of the Cape Chelyuskin area. Arctic Russia. Polar Res., 27: 222-248.

Morton, R.A., Sallenger, A.H. Jr., 2003. Morphological impacts of extreme storms on sandy beaches and barriers. J. Coast. Res., 19, 3: 560-573.

Occhietti, S., Clet, M., Richard, P., 2016. The Don Formation, Toronto, Canada: A Record of the Sangamonian Interglacial and Early Wisconsinan (Warm Part of MIS 5e to a MIS 5 Cold Substage). Quaternaire, 27(4): 275-299.

Óladóttir, B.A., Larsen, G., Sigmarsson, O., 2011. Holocene volcanic activity at Grímsvötn, Bárdarbunga and Kverkfjöll subglacial centres beneath Vatnajökull, Iceland. Bull.Volcanology, 73 (9), 1187-1208

Oppo, D.W., Horowitz, M., Lehman, S.J., 1997. Marine evidence for reduced deep water production during Termination II followed by a relatively stable substage 5e (Eemian). Paleoceanography, 12: 51-63.

Rasmussen, T.L., Thomsen, E., Kuijpers, A., Wastegård, S., 2003 . Late warming and early cooling of the sea surface in the Nordic seas during MIS 5e (Eemian Interglacial). Quatern.Sci.Rev., 22: 809-821.

Rundgren, M., Ingólfsson, Ó., Björck, S., Jiang, H., Haflidason H., 1997 . Dynamic sea-level change during the last deglaciation of northern Iceland. Boreas, 26: 201-215.

Seidenkrantz, M.S., Bormalm, L., Dansgaard, W., Johnsen, S.F., Knudsen, K.L., Kuijpers, A., Lauritzen, S.,E., Leroy, S., Mergeai, I., Schweger, C., Van Vliet-Lanoë, B., , 1996 .Two-step deglaciation at the oxygen isotope stage 6/5e transition: the Zeifen-Katetgat climatic oscillation. Quatern. Sci. Rev., 15: 63-75.

Slater, L., Jull, M., McKenzie, D., Grönvold, K. (1998). Deglaciation effects on mantle melting under Iceland: Results from the northern volcanic zone. Earth and Planetary Sciences Letter. 164:151-154.

Sveinbjornsdottir, A.E., Heinemeier, J., Kristensen, P., Rud, N., Geirsdottir, G., Hardardottir, J., 1998. Super 14C AMS dating of Icelandic lake sediments. Radiocarbon, 40: 865-872.

Swift, D.J.P., Nummedal, D., 1987 . Hummocky cross-stratification. tropical hurricanes, and intense winter storms - Discussion. Sedimentology , 34: 338-344. 
Van Vliet-Lanoë, B., Schneider, J.L., Guðmundsson, Á., Guillou, H., Nomade, S., Chazot, G., Liorziou, C., Guégan, S., 2017. Eemian estuarine record forced by glacio-isostasy (S Iceland) link with Greenland and deep sea records. Can. J. Earth Sc. In press

doi.org/10.1139/cjes-2017-0126

Tomlinson, E., Thordarson, T., Lane, C.S., Smith, V.C., Manning, C.J., Müller, W., Menzies, M., 2012. Petrogenesis of the Solheimar ignimbrite (Katla, Iceland): Implications for tephrostratigraphy. Geochim. Cosmochim. Acta., 86: 318-337.

Toucanne, S., Zaragosi, S., Bourillet, J-F., Cremer, M., Eynaud, F., Van Vliet-Lanoë, B., Fontanier, C., Turon, JL., Cortijo, E., Gibbard, P.L., 2009 .Timing of massive 'Fleuve Manche' discharges over the last 350 $\mathrm{Ka}$ : insights into the European Ice Sheet oscillations and the European drainage network from MIS 10 to 2. Quatern.Sci.Rev., 28: 1238-1256.

Van Vliet-Lanoë, B., Guillou, H., Schneider, J.L., Bergerat,F., Cavailhes, T., Allemand, P., Chazot, G., Granjean, P., Guðmundsson, Á., Liorziou, C., Passot, S., Submitted. Tectonism and volcanism forced by glaciation and deglaciation events (MIS6 to MIS 1) in southern Iceland. J.Geodyn. Submitted 2/04/2017.

Van Vliet-Lanoë, B., Bourgeois, O., Dauteuil, O., Embry, J-C., Guillou, H., Schneider J-L., 2005. Deglaciation and volcano-seismic activity in Northern Iceland: Holocene and Early Eemian (The Syðra Formation). Geodinamica Acta 18: 81-100.

Van Vliet-Lanoë, B., Guðmundsson, Á., Guillou, H., van Loon, A.J., De Vleeschouwer, F., 2010. Glacial Terminations II and I as recorded in NE Iceland. Geologos, 16 (4): 201-223.

Verpoorter, C., 2005. Enregistrement des oscillations climatiques rapides lors du dernier cycle climatique par la minéralogie de fraction argileuse terrigène en Atlantique Nord. MSc. Univ. Lille 1. 50 pp. (www.asf.epoc-u-bordeaux1.fr/theses/Manuscrits/VERPOORTER_2005.pdf).

Wada, K., Arnalds, Ó., Kakuto, Y., Wilding, L., Hallmark, C. 1992. Clay minerals of four soils formed in eolian and tephra materials in Iceland. Geoderma 52: 351-365.

Waelbroeck, C., Duplessy, J. C., Michel, E., Labeyrie, L., Paillard, D., and Duprat, J. 2001 . The timing of the last deglaciation in North Atlantic climate records. Nature 412: 724-727. 